NBER WORKING PAPER SERIES

\title{
STIMULUS EFFECTS OF INVESTMENT TAX INCENTIVES: PRODUCTION VERSUS PURCHASES
}

\author{
Christopher L. House \\ Ana-Maria Mocanu \\ Matthew D. Shapiro \\ Working Paper 23391 \\ http://www.nber.org/papers/w23391 \\ NATIONAL BUREAU OF ECONOMIC RESEARCH \\ 1050 Massachusetts Avenue \\ Cambridge, MA 02138 \\ May 2017
}

We thank Anusha Chari, Guiseppe Fiori, Simon Gilchrist, Adam Guren, Greg Kaplan, John Leahy, James Nason, Jonathan Parker, Nora Traum and seminar participants at Boston University, University of Chicago, Johns Hopkins, LSE, MIT, University of Melbourne, University of Michigan, University of North Carolina Chapel Hill, North Carolina State University, Northwestern, and the Federal Reserve Board for helpful comments and suggestions. This research is supported by the National Science Foundation (SES 0962219). The views expressed herein are those of the authors and do not necessarily reflect the views of the National Bureau of Economic Research.

NBER working papers are circulated for discussion and comment purposes. They have not been peer-reviewed or been subject to the review by the NBER Board of Directors that accompanies official NBER publications.

(C) 2017 by Christopher L. House, Ana-Maria Mocanu, and Matthew D. Shapiro. All rights reserved. Short sections of text, not to exceed two paragraphs, may be quoted without explicit permission provided that full credit, including $\odot$ notice, is given to the source. 
Stimulus Effects of Investment Tax Incentives: Production versus Purchases

Christopher L. House, Ana-Maria Mocanu, and Matthew D. Shapiro

NBER Working Paper No. 23391

May 2017

JEL No. E22,E62,H25

\section{ABSTRACT}

The distinction between production and purchases of investment goods is essential for quantifying the response to changes in investment tax incentives. If investment goods are tradeable, a large fraction of the demand from changes in tax subsidies will be met from abroad. This difference between production and purchases implies that investment tax incentives will lead to more capital accumulation, but less stimulus to economic activity relative to a no-trade counterfactual. Domestic capacity to produce investment goods is less than perfectly elastic because of quasi-fixed factors of production, adjustment costs, and specialization of labor. This paper builds these features into a DGSE model where key parameters are estimated to match the reduced-form response of investment production and purchases to tax incentives. Typical investment tax policies result in equipment purchases that are split roughly half between domestic and foreign production of equipment.

Christopher L. House

University of Michigan

Department of Economics

238 Lorch Hall

Ann Arbor, MI 48109-1220

and NBER

chouse@umich.edu

Ana-Maria Mocanu

Amazon

410 Terry Ave. North

Seattle, WA

98109-5210

anamaria@amazon.com
Matthew D. Shapiro

Department of Economics

University of Michigan

611 Tappan St

Ann Arbor, MI 48109-1220

and NBER

shapiro@umich.edu

A online appendix is available at http://www.nber.org/data-appendix/w23391 


\section{INTRODUCTION}

Does capital accumulation respond strongly to investment tax incentives? Do investment tax incentives stimulate the economy? This paper investigates whether the answer to these two questions is different. The neoclassical theory of investment demand implies that business investment should respond strongly to changes in the after-tax price of capital-particularly for temporary tax policies. Such an increase in purchases of capital goods, however, need not stimulate domestic economic activity if capital goods are imported or if the domestic supply of investment goods is relatively inelastic. Indeed, imported capital equipment has become a common feature of for the U.S. economy over the past 50 years. Figure 1 plots the ratio of the total dollar value of gross imports and exports of capital equipment relative to total equipment investment for 1967-2015. While capital imports were less than five percent of aggregate equipment investment in 1967, this ratio has steadily risen to more than fifty percent in 2015. Capital exports have also gone up steadily over this time period (though not quite as rapidly as imports). Hence, the U.S. economy is increasingly open to trade in capital equipment as both supplier and demander of capital equipment.

In a framework that distinguishes purchases and production, we present both reducedform estimates and structural estimates of a dynamic equilibrium model of the effects of investment tax subsidies. Because different capital goods receive different investment tax treatments, our empirical and modeling frameworks also feature an analysis of the reallocation of inputs and production across sectors in addition to the aggregate effects of investment tax policy. These approaches show that indeed the production/purchase distinction is essential for understanding the effects of changes in tax policy and for quantifying the magnitude of responses to specific policy interventions.

Notwithstanding the volatility and measurement limitations of industry-level investment data, clear and consistent patterns are evident. Our reduced-form estimates imply that a one percentage point investment tax incentive increases purchases of capital equipment by roughly 2 percent. Domestic production of capital equipment also increases, though by only about 1 percent. Thus, tax incentives succeed on both margins - they both encourage businesses to expand physical capital, and encourage increased domestic production. Yet, the response of production is about half as large as the increase in purchases.

We find little evidence for pass-through of investment tax subsidies to the pre-tax price of 
capital goods. Although there are empirical specifications in which a one percentage point subsidy leads to roughly a one percent increase in prices, such findings are not robust to even modest changes in the econometric specification. Overall, the results suggest that either there are no discernible impacts of investment tax subsidies on prices or that the true impact is difficult to measure accurately in the available data. This result differs from Goolsbee's (1998) finding that investment subsidies push up the prices of investment goods. We can replicate his findings using his original sample period and vintage data. Data revisions and additional observations have both led to a reduction in the estimated price responses found in his earlier study. Thus, the effective supply of new capital goods appears substantially more elastic than earlier data suggest.

In the second part of the paper, we construct a general equilibrium model that has key features for understanding the dynamic supply of investment goods. Some of these features increase the effective short-run supply elasticity of capital goods, while others work to reduce it. In addition to imports and the fact that investment goods production is a relatively small part of the economy, the model allows for variable utilization, factor mobility, and factor accumulation as other margins of domestic supply of capital goods. In addition to standard general equilibrium effects, factors adjustment and sectoral specificity of labor limit the elastic supply of capital. Our DGSE model integrates all these margins in a framework that highlights both industrial heterogeneity and a meaningful distinction between production and purchases of capital goods. The reduced-form econometric specification in the first part of the paper serves as the auxiliary model which allows us to estimate the elasticity of supply for foreign equipment-the key structural parameter governing the difference between production and purchases of domestic investment goods. We then use the estimated structural model to study the effects of investment subsidies that match features of commonly-enacted tax policies.

The model illustrates important dynamic effects of the response to policy. In the short run, the increase in investment purchases is largely accommodated by an expansion of imports of equipment. As a result, the immediate stimulus effects of investment tax incentives exhibit "leakage" in the sense that the subsidies are stimulating production and employment of over-seas capital producing firms. Over time, investment, domestic production of capital goods, equipment exports, consumption and GDP all increase. The delayed increase in exports of equipment is notable. After investment subsidies expire, as often happens, the increased capacity for domestic production of equipment persists and results in above-trend production of capital goods and 
equipment exports. Hence, while investment subsidies adversely affect the trade balance in equipment initially, subsequently such policies have favorable effects on the trade balance.

\section{RELATED LITERATURE}

Economists have attempted to quantitatively address the reaction of investment spending to changes in the after-tax price of capital goods at least since Hall and Jorgensen (1967). ${ }^{1}$ Our paper adds to a resurgence of work addressing the effects of tax policy on investment. This renewed interest in investment tax policy is driven in part by the availability of new data and in part by a renewed interest on the part of policy makers in the viability of investment incentives as a policy tool.

Goolsbee (1998) considers whether the pre-tax price of investment typically increases following investment subsidies. For many of the types of capital goods in his dataset, prices appear to rise almost one-for-one with the subsidy. Goolsbee's conclusion is natural-investment tax incentives might have little impact on investment spending because the supply of new capital is effectively price-inelastic. This finding has been challenged by several recent papers including Whelan (1999), House and Shapiro (2008), Edgerton (2010), Mian and Sufi (2012) and Sallee (2011). Whelan argues that after controlling for input cost shocks, there is little evidence that investment incentives bid up prices. House and Shapiro (2008) focus on the cross-sectional impact of bonus depreciation in the early 2000s and conclude that, at least for that episode, there is no clear relationship between the subsidy and capital goods prices.

There are also recent studies that suggest that real investment spending does react to subsidies and other shocks. The estimated reactions to bonus depreciation in House and Shapiro (2008) were surprisingly large. Edgerton (2010) argues that in the mid-2000s, housing prices, farming prices and oil prices all experienced dramatic increases unrelated to the supply of capital goods. He then looks at the production and pricing of construction equipment, agricultural equipment and mining equipment and finds little evidence that prices of these goods rose despite increases in the production of these capital goods. Mian and Sufi (2012) find that the CARS program (better known as "Cash for Clunkers") sharply increased automobile purchases while the subsidy was in place. Zwick and Mahon (2017) use business tax return data to re-examine the

\footnotetext{
${ }^{1}$ The existing literature on investment demand and investment tax incentives is vast and an adequate summary is beyond the scope of this paper. Foundational contributions include Jorgenson (1963), Abel (1981), Hayashi (1982), and Summers (1981).
} 
effects of bonus depreciation and find that investment responded strongly to the subsidy. Zwick and Mahon pay particular attention to financially constrained firms whom, they argue, reacted most sharply to the bonus depreciation subsidy.

\section{DATA AND CONCEPTS}

\section{A. Production and Purchases}

Data on investment purchases come from nominal investment spending and investment prices in the Bureau of Economic Analysis’ (BEA) underlying detail tables. We define real purchases as the ratio of total nominal purchases to the type-specific price index. Our data on quantities and prices of domestic production of equipment come from the NBER-CES Manufacturing Productivity Database. ${ }^{2}$ The NBER database also provides data on inputs and total factor productivity for equipment. Because purchases and production of structures are identical, we use the BEA data for them. We create a quarterly panel of 30 equipment types and 20 structure types shown in Tables 1A and 1B from 1959 to 2009. The BEA purchase data are much more detailed than the NBER production data. Appendix A contains details of how we harmonize the data by type and frequency.

The top panel of Figure 2 shows purchases and production for general industrial equipment (one of the 30 investment categories in our equipment dataset). The bottom panel shows the real relative price. The figure illustrates three noteworthy features common to many investment types in our sample.

First, the quantity series exhibit dramatic movements over time. Real quantities (for either purchases or production) regularly change by more than twenty percent from one year to the next. In contrast, real relative prices are much less volatile. The average volatility of investment purchases and production is 11 and 8 percent respectively. In contrast, the average volatility of investment prices is only two percent. Edgerton (2010) argues that, on its face, this observation alone suggests that the supply of investment goods is highly elastic.

Second, while domestic production exceeds purchases for the entire sample period, the gap between the two is gradually closing. As U.S. manufacturing has declined, domestic firms have become more and more reliant on imported capital goods.

\footnotetext{
2 This dataset was assembled by Eric Bartelsman, Randy Becker, Wayne Gray and Jordan Marvakov. The raw data are freely available at the NBER data website. See Bartelsman and Gray (1996).
} 
Third, there is a dramatic transitory downward spike in the relative price in the early-mid 1970's. This spike is associated with a sharp increase in world oil prices at the same time. Following the increase in oil prices, the Personal Consumption Expenditure (PCE) price series used to construct relative investment-goods prices reacts rapidly while the investment price indices react with a modest delay. This might be because oil prices are passed through directly to gasoline prices, which receive substantial weight in the PCE deflator. The timing of price increases across goods was also likely affected by the Nixon price controls. We address both oil price variation and the Nixon price controls in the econometric specification.

\section{B. Investment Tax Subsidies}

Tax policy affects the after-tax purchase price of investment goods via depreciation allowances, the investment tax credit, and tax rates. Building on the framework of Hall and Jorgenson (1967) and using data provided by Dale Jorgenson, we define the comprehensive investment tax subsidy as the tax saving per unit of investment goods purchased. ${ }^{3}$ Denote the ITC for type $m$ capital at time $t$ as $I T C_{t}^{m}$. Let $z_{t}^{m}$ denote the present discounted value of tax depreciation allowances for type $m$ capital purchased at time $t$. That is, if $1+i_{t}$ is the gross nominal interest rate and $\left\{D_{j, t}^{m}\right\}_{j=1}^{R}$ is a sequence of tax depreciation deductions for a unit of type $m$ capital with a tax life of $R$ periods, then

$$
z_{t}^{m}=\sum_{j=1}^{R} \frac{D_{t, j}^{m}}{\prod_{s=0}^{j-1}\left(1+i_{s}\right)} .
$$

The comprehensive subsidy $\zeta_{t}^{m}$ is then

$$
\zeta_{t}^{m}=I T C_{t}^{m}+\tau_{t}^{\pi} z_{t}^{m} .
$$

This measure assumes that the firm writes off depreciation deductions against the corporate tax rate $\tau_{t}^{\pi} \cdot{ }^{4}$

Tables $1 \mathrm{~A}$ and $1 \mathrm{~B}$ list the average value of the comprehensive subsidy for each

\footnotetext{
${ }^{3}$ The original annual data on the ITC and the discounted value of depreciation deductions are available from Jorgenson and Yun (1991). We are grateful to Dale Jorgenson and Jon Samuel for providing updates to these data. To match the frequency of our data on investment and investment prices, we construct a quarterly version of these data using the historical record of investment tax changes, some of which have effective dates that do not correspond to calendar years. See Appendix A for further details.

${ }^{4}$ Several details of tax policy affect the calculation of the comprehensive subsidy. First, how the ITC affects the basis for depreciation has changed over time. Additionally, since 2002, there has been "bonus depreciation" that allows immediate write-off of some types of investment in varying amounts. Our implementation of $z_{t}^{m}$ includes an adjustment for how the ITC affects the basis and for bonus depreciation. See Appendix A for details.
} 
investment category. The comprehensive subsidy can change for a variety of reasons. Changes (or expected changes) in nominal interest rates, changes in depreciation schedules or changes in the corporate tax rate can all cause changes in $\zeta_{t}^{m}$. The dependence of the comprehensive subsidy on the corporate tax deserves special mention. Notice that the value of the subsidy increases with $\tau_{t}^{\pi}$ since the firm is writing off depreciation against the corporate income tax rate. It is not necessarily true however, that an increase in $\tau_{t}^{\pi}$ will lead to an increase in investment demand. While the effective subsidy to new capital has gone up, the value of the capital itself may have gone down.

Mapping the comprehensive subsidy into the decisions problem of the firm yields an alternative formulation that has been used in the literature. If there were no change in the price of capital over time, the firms' first order condition for capital implies that firms would invest to the point at which the after-tax marginal product of capital is equal to the tax-adjusted user cost of capital. In such a situation, the first order condition for type $m$ capital would require

$$
M P_{t}^{k, m}=p_{t}^{m}(r+\delta) \times \frac{1-\zeta_{t}^{m}}{1-\tau_{t}^{\pi}},
$$

where $M P_{t}^{k, m}$ is the marginal product of type $m$ capital and $p_{t}^{m}$ is the real relative price of type $m$ capital. Because the "normal" user cost is simply the term $p_{t}^{m}(r+\delta)$ in equation (3), we refer to this measure as the tax adjustment to the user cost. ${ }^{5}$ For comparability with the investment tax credit $I T C_{t}^{m}$ and the comprehensive subsidy $\zeta_{t}^{m}$, we reverse the sign so that an increase in this measure corresponds to a positive subsidy. More specifically, we denote the tax adjustment to the user cost as $\Phi_{t}^{m}$ with

$$
\Phi_{t}^{m} \equiv \frac{\zeta_{t}^{m}-1}{1-\tau_{t}^{\pi}}=\frac{I T C_{t}^{m}+\tau_{t}^{\pi} z_{t}^{m}-1}{1-\tau_{t}^{\pi}} .
$$

Unlike under the comprehensive subsidy (2), under the tax adjustment to the user cost (4) an increase in the corporate profit tax $\tau_{t}^{\pi}$ reduces the firm's incentives to accumulate capital. While it enhances the value of the tax subsidy (through the effect on $z_{t}^{m}$ ) an increase in the corporate

\footnotetext{
${ }^{5}$ Goolsbee (1998) calls this variable simply the "tax term." Note that this specification of the tax-adjusted user cost implicitly adopts the "new view" of corporate profit taxation in which we assume that marginal investment projects are financed with retained earnings and are thus unaffected by taxation of distributed corporate earnings. We will return to this issue in the modeling section below, where we observe that the tax on distributions cancels from the relevant first-order conditions. For discussion of this point see Sinn (1991).
} 
profit tax reduces the after-tax marginal product of capital by more.

Figure 3 plots three measures of the investment tax subsidy for general industrial equipment: the comprehensive subsidy $\left(\zeta_{t}^{m}\right)$, the tax adjustment to user cost $\left(\Phi_{t}^{m}\right)$, and the investment tax credit $\left(I T C_{t}^{m}\right.$ ). (In the figure, we normalize $\Phi_{t}^{m}$ so that it begins at 0 .) Notice that the three measures exhibit similar movements over time. Changes in the ITC were made at the same time as changes in tax depreciation rates and changes in the tax rate on corporate profits. While the overall time series variation is similar across the three measures, it is not identical. For instance, while the ITC has been zero since the Tax Reform Act of 1986, there are nevertheless significant changes in the comprehensive investment tax subsidy. These changes arise from changes in tax depreciation and changes in nominal interest rates, both of which factor directly into the computation of the comprehensive subsidy.

Figure 4 plots the comprehensive subsidy $\zeta_{t}^{m}$ for all of the investment types in our dataset. Notice that, in addition to the time series variation shown in Figure 3, there is also a substantial amount of variation across capital types. One particular event which featured pronounced cross sectional differences in tax treatment was the so-called "bonus depreciation" allowance introduced in 2002. This policy can be seen clearly in Figure 4 as a sudden change in investment tax incentives for a few types starting in 2003. See House and Shapiro (2008) for discussion of this policy.

\section{Aggregate Data}

In addition to the type-specific data on investment, investment prices and investment tax subsidies, we also make use of several aggregate data series. Specifically, we use data on real GDP, real oil prices and dummy variables for the Nixon price controls. Quarterly data on real GDP are from the BEA. To construct real oil prices, we average the monthly spot oil price (West Texas Intermediate) to construct a quarterly nominal series. We then take the ratio of the quarterly oil price to the PCE deflator for non-durables. Finally, the Nixon price controls were part of the Economic Stabilization Program and went into effect on August 15, 1971 and were removed on April 30, 1974. ${ }^{6}$ The price controls play a non-trivial role in price data for that period. We accommodate this policy with dummy variables. Given the timing of the legislation,

\footnotetext{
${ }^{6}$ Source: National Archives. See http://www.archives.gov/research/guide-fed-records/groups/432.html.
} 
our dummy variable for the Nixon price controls takes the value 0.6 for 1971:3 and 1.0 for 1971:4 to $1974:{ }^{7}$

\section{REDUCED-FORM EFFECTS OF INVESTMENT TAX SUBSIDIES}

This section presents reduced-form empirical results. We begin in section 4.1 by discussing our basic regression specification. In section 4.2 we present the main estimates. The reduced-form coefficients later serve as a basis for the structural estimate of the supply elasticity of foreign equipment used in the quantitative model.

\section{A. Econometric Specification}

We estimate the effects of investment tax subsidies on the production and purchases of investment goods, their prices, imports and exports of capital goods as well as variables that reflect producer activity including employment, payroll, production employees, production hours, production wages, TFP, inventories, the cost of materials and the cost of energy used by producers. We present pooled OLS results to paint a broad picture of how tax subsidies affect the production and purchases of capital goods.

The reduced-form econometric specification we consider is

$$
y_{t}^{m}=b_{1} \cdot \zeta_{t}^{m}+b^{m}(t)+\Gamma^{m} \mathbf{X}_{t}^{m}+e_{t}^{m}
$$

where $y_{t}^{m}$ are different left-hand-side variables, which may be investment, production, prices, and so on. The index $m$ denotes the type of investment good and $t$ denotes time. Separate estimates are presented for equipment and structures. The variable $\mathbf{X}_{t}^{m}$ is a set of covariates (which could include type-specific data and/or aggregate data) and $\Gamma^{m}$ is the associated set of type-specific regressors. For each type, we also include a type-specific time trend given by $b^{m}(t)$. The coefficient of interest in equation (5) is $b_{1}$. This coefficient, which is constrained to be common across the types of capital goods (thus there is no superscript $m$ ), describes the average change in the variable of interest $y_{t}^{m}$ associated with changes in the comprehensive investment tax subsidy. It is identified from both the persistent time series variation in tax subsidies and the cross-sectional variation in how the subsidies affect types.

\footnotetext{
${ }^{7}$ Our dates and the dummy variable specification are the dates used by Goolsbee (1998). Robert J. Gordon (1990) dates the expiration of the price controls as 1974:4.
} 
We present results for four different regression specifications with different controls. The first is a parsimonious specification including, in addition to the subsidy itself, only a constant and a linear trend. The second and third specifications include a constant, a time trend and a set of macroeconomic covariates: HP-filtered GDP and dummy variables for years affected by the price controls during the Nixon administration. The third specification includes the real price of oil. The fourth specification uses a linear trend, all macroeconomic covariates, and also includes two lags and two leads of the subsidy variable. This last specification is intended to capture anticipation effects or measurement lags in the data. Because investment and investment policy are highly correlated across time and across capital types, we use the heteroskedasticity and autocovariance consistent estimate of the standard errors proposed by Driscoll and Kraay (1998).

Before proceeding to the results themselves it is appropriate to make a remark about the interpretation of the findings. In particular, we want to be upfront about the potentially important endogeneity problems our estimates face. Investment tax policy in the U.S., while capricious, is not truly econometrically exogenous. To the extent that investment tax incentives react endogenously to economic conditions, as for instance the CARS program did in the Mian and Sufi (2012) study, our results will be biased indicators of the true causal effects of investment tax subsidies. On the other hand, many of the legislative changes to investment tax incentives in our sample were made without direct connection to contemporaneous economic conditions and thus were in a certain sense "exogenous" changes. Appealing to a narrative assessment of the legislation, Romer and Romer (2009) argue that most of the major modifications to tax policy in our sample frame were motivated by long-run concerns (see Appendix Table A.1. for the RomerRomer classifications). In particular, the motivations explicitly cited by law makers when they expanded investment subsidies in the 1960s and 1970s often centered on increasing long-run growth by encouraging firms to increase and modernize the capital stock. When the subsidies were pared back in the 1980s, the goals were reducing the deficit and eliminating tax distortions.

The historical chronology of the main legislative changes to the investment tax subsidies is presented in Table 2. In addition to providing information about the specifics of the policies driving the measures of tax subsidies, the table provides information about the duration of policy that will inform our simulations. The table lists both changes to the ITC and changes to the treatment of tax depreciation allowances. The table also lists the stated duration and actual duration of the policies. Laws are described as "permanent" if the legislation contained no 
explicit stipulations of subsequent revisions or sunsets in the policies. That is, if the bill did not include an end-date, it is listed as permanent in the table. Temporary policies have an end-date included in the legislation. The actual duration of the policy is measured based on the next legislated change in the tax treatment of investment. We date these policy changes according to the dates when the policies were enacted and not necessarily when they went into effect. Changes to investment tax policy have historically been quite common. Typically the tax treatment of investment changes roughly every two and a half years. Policies with announced end-dates (explicitly temporary policies) are rare, though they appear to be more common in recent history. We do not parameterize the duration of the policy for the reduced-form estimate; the subsidy is simply entered at its current value. Hence, the estimated reduced-form response of variables to the subsidy reflects both the average size of the subsidy and its average expected duration. We revisit the evidence and implications of duration when we turn to the structural estimation and simulation in Sections V and VI.

\section{B. Reduced-Form Estimates}

Table 3 reports the reduced-form estimates for how the comprehensive investment subsidies affect the production and purchases of capital goods. Table 4 shows how the subsidy affects equipment prices; employment, hours, wages, TFP, the cost of materials, and the cost of energy in the production of equipment. Table 4 also presents estimates of the effect of subsidies on the production and prices of structures. Both tables include estimates for the four econometric specifications discussed above. The data are as described in Section III and Appendix A. For equipment, the reduced-form estimates use the types in Table 1A excluding computers and software. We exclude computers and software because they have such dramatic changes in prices owing to technological progress. For structures, the reduced-form estimates use the types in Table 1B excluding the three residential types. ${ }^{8}$

Purchases and Production of Capital Goods. Table 3 shows our central reduced-form empirical finding, that the response of purchases of equipment to the comprehensive subsidy $\zeta_{t}^{m}$ is almost twice as large as the response of domestic production. Looking across the first row, the estimates indicate that a one percentage point investment subsidy is associated with an increase in

\footnotetext{
${ }^{8}$ When we turn to the model, all types are included because the general equilibrium model needs to account for all components of investment. See Section V.
} 
investment production of between 1.08 and 1.19 percent. The second row reports the estimates for investment purchases. Again, the results are economically significant-a one percentage point increase in the investment subsidy is associated with an increase in investment purchases of between 1.76 and 1.97 percent. The third row of Table 3 reports the differences of the coefficient estimates. For instance, if we focus on the column for the "Macro covariates" specification (column 3) the estimated response of production associated with the comprehensive subsidy is 1.08 while the estimated response of purchases to variations in the comprehensive subsidy is 1.76. That is, for every one percentage point increase in the investment tax subsidy, purchases of investment goods rise by 1.76 percent while domestic production of capital goods increases by only 1.08 percent. The difference between the estimates is 0.68 with a standard error of 0.11 , so the difference is strongly statistically significantly different from zero. The covariance of the purchases and production coefficient estimates are strongly positive, so the standard error of their differences is substantially less than the sum of the standard errors. Hence, there is strong evidence of substantial "leakage" — that is, about half of the stimulus benefits foreign rather than domestic producers. ${ }^{9}$

Equipment Prices. Goolsbee's 1998 paper made a case that one of the main reasons that investment tax incentives were not as effective as one might expect is that much of the subsidies are passed through to capital goods prices. An investment subsidy might bid up prices of capital goods, but not cause increased production. The first row of Table 4 presents estimates of the reaction of equipment prices to the comprehensive subsidy using the same four specifications of covariates as in Table 3. Unlike Goolsbee's estimates, our estimates show little or no price response for equipment. The coefficients estimates are close to zero with fairly tight confidence intervals. From the point of view of basic economic analysis, sensible estimates would be anywhere between 0.00 and 1.00 depending on the duration of subsidy, the supply elasticity, the openness of the economy, and durability of the capital goods. ${ }^{10}$ As we emphasize in this paper,

\footnotetext{
${ }^{9}$ These findings carry over to the other measures of investment subsidies as well. For the ITC, depending on the econometric specification, production increases by between 2.09 and 2.91 percent while purchases rise by between 2.94 and 3.31 percent. For the tax adjustment to the user cost $\left(\Phi^{m}\right)$ the estimates show a similar pattern though they are less statistically significant. See Appendix Table B.1 for these results.

${ }^{10}$ The standard neoclassical theory of investment demand predicts that, particularly for temporary investment subsidies, capital goods prices must rise nearly one-for-one with the subsidy regardless of the elasticity of supply.
} 
the open economy channel substantially attenuates the price response. This analysis contrasts with Goolsbee’s closed-economy, inelastic supply analysis and findings.

We have made considerable efforts to explain the difference between our findings and the findings in Goolsbee's earlier paper. The two sets of estimates differ both in sample period (Goolsbee's sample was 1962-1988 while we use data from 1959-2009) and in the vintage of the data - that is, the data have been updated and revised substantially since Goolsbee's original paper was published. Both factors contribute to the different results. Appendix B presents a detailed comparison between our findings and Goolsbee's results. In brief, we can replicate Goolsbee's results for his estimation period using vintage data. The main reason for differences between our results and his is that we study a longer, more recent sample period and the data have been revised.

Employment, Wages, Inputs and Productivity of Equipment Producers. Another way to quantify the effects of investment tax subsidies is to examine the productive inputs of capital producing firms. The second three rows of Table 4 report results for employment, hours and wages of production workers in equipment-producing firms. Consistent with the results from Table 3, employment and hours are positively associated with high investment subsidies. The response of employment and hours to the subsidy are strong, but consistently less than the response of production. This finding is consistent with short-run increasing returns to labor, an issue we will return to in the model section.

Wages at equipment-producing firms also increase with investment subsidies. Goolsbee (1998) also emphasizes this point and our updated estimates agree with his earlier results. Note that the response of wages, however, is very imprecisely estimated, and very unstable across specifications.

Table 4 shows additional measures of production activity at equipment-producing firms. Consistent with earlier results, materials costs, energy costs and measured total factor productivity all rise in response to investment subsidies, which suggests that these firms do actively expand production of capital goods. A one percentage point investment subsidy is associated with an increase in measured TFP of about $1 / 3$ percent. Materials inputs increase

Thus, observing sharp price increases following an investment subsidy does not suggest that the policy has little effect. See House and Shapiro (2008) for extended discussion of this point. 
roughly one-for-one with the subsidy. The response of energy is imprecisely estimated. Overall, these responses are consistent with an increase in production of capital goods. The increase in measured productivity suggests that firms are varying unmeasured inputs in addition to measured factor inputs such as worker effort.

Investment Subsidies and Structures Investment. While much of the existing literature focuses on investment in equipment, U.S. tax policy also provides varying incentives for purchases of business structures. Importantly, the neoclassical theory of investment suggests that structures investment should be much more sensitive to predictable variations in its after-tax price than equipment investment (see House and Shapiro 2008). Unlike equipment investment, there is essentially no difference between domestic purchases and domestic production of business structures (i.e., there are no imported structures to speak of).

The last two rows of Table 4 present estimates on the effect of investment subsidies for investment in business structures. As we found with the effects of subsidies on purchases and production of equipment, purchases (identically production) of structures respond to variations in investment tax incentives. For a one percentage point investment tax subsidy, structures investment rises between one-half and 1 percent. Unlike the findings for equipment, there is evidence that structures prices do respond strong to investment tax incentives though there is substantial variation in the estimates across econometric specifications.

Although investment subsidies for structures are generally lower than subsidies for equipment, and notably structures do not receive the ITC, the estimated effects are sizeable. Overall, the reduced-form estimates for structures are larger than the estimates for equipment. This pattern could be generated by a variety of factors. First, equilibrium complementarities between equipment and structures may cause structures investment to rise when tax policies stimulate investment in equipment. Second, changes in tax depreciation allowances, which directly affect structures, are correlated with changes in the ITC. The most prominent example is the Tax Reform Act of 1986, which both repealed the ITC and dramatically limited accelerated depreciation. Many other legislative changes modified both forms of tax incentives in the same direction (see Table 2). Lastly, structures have low rates of economic depreciation, which implies high intertemporal elasticities of substitution. As a result, structures investment is more sensitive to changes in the after-tax price of capital. 


\section{QuAnTITATIVE ModeL}

In this section we present a quantitative dynamic general equilibrium model that captures the key features observed in the reduced-form relationships between investment subsidies and the production and purchases of capital goods. To capture the heterogeneity in production, use, and tax treatment of capital, the model has $M$ capital-producing industries matching the level of detail in Section IV. The model has a single industry that produces the numeraire good $Q$, which can be used for consumption, government purchases, material inputs, or exports. The model features variable effort and capital and labor adjustment costs in all sectors. Labor income, dividends and profits are subject to distortionary taxes, while investment receives subsidies. Equipment and the numeraire good can be traded internationally. We impose period-by-period balanced trade, which requires that trade in equipment is accompanied by offsetting trade flows of the numeraire good. ${ }^{11}$ Structures are not traded, so the production and investment in structures are equal. We use the model to estimate the supply elasticity of foreign equipment using an indirect inference procedure that targets the reduced-form empirical results in section IV. We then use the model to quantify the aggregate effects of investment tax policy.

\section{A. Households}

The representative household consumes the non-durable final good, supplies labor and effort on the job, saves at the risk-free rate, pays taxes and owns the capital stock. The household derives utility from consumption and disutility from labor and effort. The household's flow utility function is

$$
U\left(C_{t}, L_{t}, e_{t}^{1}, \ldots, e_{t}^{M}, e_{t}^{Q}\right)=\frac{C_{t}^{1-\frac{1}{\sigma}}}{1-\frac{1}{\sigma}}-\phi \frac{L_{t}^{1+\frac{1}{\eta}}}{1+\frac{1}{\eta}}-\psi\left(e_{t}^{Q} n_{t}^{Q}+\sum_{m=1}^{M} e_{t}^{m} n_{t}^{m}\right)
$$

where

$$
L_{t}=\left[a^{Q}\left(n_{t+j}^{Q}\right)^{1+\psi_{n}}+\sum_{m=1}^{M} a^{m}\left(n_{t+j}^{m}\right)^{1+\psi_{n}}\right]^{\frac{1}{1+\psi_{n}}}
$$

is a labor index that aggregates work over the $M+1$ sectors with the constant elasticity of substitution (CES) form. Total hours spent working is denoted by

\footnotetext{
${ }^{11}$ We suppress international borrowing and lending primarily for simplicity. Whether we allow international borrowing has little effect on the structural estimate of the supply elasticity of foreign investment goods, but it does matter for the timing of the model-implied aggregate effects of stimulus policy. We report results allowing for international borrowing and lending in Appendix E. See also the discussion of the policy simulations in Section VI .
} 


$$
N_{t}=n_{t}^{Q}+\sum_{m=1}^{M} n_{t}^{m} .
$$

The elasticity of labor substitution in equation (7) across sectors is $\psi_{n}$. If $\psi_{n}>0$, then there is limited substitutability of labor across sectors. We introduce this form of labor specificity as a realistic device for specialization in labor that limits the flexibility in changing the composition of output. It thus limits the response to an investment tax subsidy. Indeed, a permanent investment tax subsidy will drive a permanent wedge between wages in subsidized and notsubsidized sectors. This specification also nests the special case when $\psi_{n}=0$, where the household supplies labor to each sector symmetrically. The household spends $n_{t}^{m}$ hours working in each capital-producing sector $m$ and $n_{t}^{Q}$ hours working in the final goods sector. For each hour of labor, the household receives pre-tax real wages $W_{t}^{m}$ and $W_{t}^{Q}$ in the capital industries and the numeraire sector, respectively.

We choose parameters to ensure that, in the steady state, the CES labor aggregate and total hours are equivalent, i.e. $L=N$. This relationship is obtained by choosing the constant terms $a^{Q}, a^{m}$ in (7) such that $a^{m}=\left(n^{m} / N\right)^{-\psi_{n}}$ for $m=1, \ldots, M$. We introduce variable effort, a margin of adjustment that makes supply more elastic. Effort in each capital-goods producing sector $m$ is denoted by $e_{t}^{m}$ and $e_{t}^{Q}$ indicates effort in the numeraire sector. Each hour of effort entails a utility cost of $\psi$ to the representative household.

To summarize, each period the household seeks to maximize its expected discounted utility

$$
E_{t}\left[\sum_{j=0}^{\infty} \beta^{j}\left\{\frac{C_{t+j}^{1-\frac{1}{\sigma}}}{1-\frac{1}{\sigma}}-\phi \frac{L_{t+j}^{1+\frac{1}{\eta}}}{1+\frac{1}{\eta}}-\psi\left(e_{t+j}^{Q} n_{t+j}^{Q}+\sum_{m=1}^{M} e_{t+j}^{m} n_{t+j}^{m}\right)\right]\right\}
$$

subject to the budget constraint

$$
\begin{array}{r}
\left(1-\tau^{N}\right)\left[W_{t}^{Q} n_{t}^{Q}+\sum_{m=1}^{M} W_{t}^{m} n_{t}^{m}\right]+\left(1-\tau_{t}^{d}\right)\left(1-\tau_{t}^{\pi}\right) \sum_{m=1}^{M} R_{t}^{m} K_{t}^{m}+T_{t}+S_{t-1}\left(1+r_{t-1}\right) \\
=C_{t}+S_{t}+\left(1-\tau_{t}^{d}\right) \sum_{m=1}^{M} P_{t}^{m}\left[1-\zeta_{t}^{m}\right]\left(I_{t}^{m}+I M P_{t}^{m}\right)
\end{array}
$$

and the capital accumulation constraints 


$$
K_{t+1}^{m}=K_{t}^{m}\left(1-\delta^{m}\right)+I_{t}^{m}+I M P_{t}^{m}
$$

and the definition of $L$ in equation (7). The representative household owns the capital stock $K_{t}^{m}$ for all types $m=1, \ldots, M$. The household may purchase new capital from domestic producers $I_{t}^{m}$ or from foreign importers $I M P_{t}^{m}$. The pre-tax price of type $m$ capital in units of the numeraire good at date $t$ is $P_{t}^{m}$. The pre-tax real rental price of type $m$ capital is $R_{t}^{m}$. Each type of capital has a type-specific depreciation rate $\delta^{m}$. In addition to investing in physical capital, the household saves in bonds $S_{t}$, which earn the net real safe rate of return $r_{t}$.

One of the key features of the model is its realistic treatment of tax policy, which allows us to analyze the aggregate effects of investment tax incentives once we estimate the structural parameters. Purchases of capital goods receive type-specific investment subsidies. The comprehensive investment tax subsidy for type $m$ at date $t$ is $\zeta_{t}^{m}$. Capital income is taxed twiceonce at the profit tax rate $\tau_{t}^{\pi}$ and again according to the tax rate on distributed capital earnings $\tau_{t}^{d}$. Labor income is taxed at the constant rate $\tau_{t}^{N}$. In addition to the distortionary taxes $\tau^{N}, \tau_{t}^{d}$ and $\tau_{t}^{\pi}$, the government also remits excess revenue to the household through a lump-sum transfer (or tax) $T_{t}$.

The solution to the household's optimization problem requires the following first order conditions,

$$
\begin{gathered}
W_{t}^{m}=\frac{C_{t}^{\frac{1}{\sigma}}}{1-\tau^{N}}\left[\phi L_{t}^{\frac{1}{\eta}}\left(\frac{L_{t}}{L}\right)^{-\psi_{n}}\left(\frac{n_{t}^{m}}{n^{m}}\right)^{\psi_{n}}+\psi e_{t}^{m}\right], \\
C_{t}^{-\frac{1}{\sigma}}=\beta\left(1+r_{t}\right) E_{t}\left[C_{t+1}^{-\frac{1}{\sigma}}\right], \\
q_{t}^{m}=\beta E_{t}\left[C_{t+1}^{-\frac{1}{\sigma}}\left(1-\tau_{t+1}^{\pi}\right)\left(1-\tau_{t+1}^{d}\right) R_{t+1}^{m}+q_{t+1}^{m}\left(1-\delta^{m}\right)\right] \\
q_{t}^{m}=C_{t}^{-\frac{1}{\sigma}}\left(1-\tau_{t}^{d}\right) P_{t}^{m}\left[1-\zeta_{t}^{m}\right] .,
\end{gathered}
$$

Equation (12) is the household's labor supply condition for sector $m$ (abusing notation somewhat, we have implicitly included the first order condition for $m=Q$ in equation (12) as 
well). This equation serves as the wage-effort menu faced by the firms. Equation (13) is the stochastic Euler equation. Equation (14) is the shadow value of type $m$ capital and equation (15) is investment demand for type $m$ capital (either imported or domestically produced). ${ }^{12}$

\section{B. Firms and Production}

Aggregate Capital Services. The individual capital types $m=1, \ldots M$ owned by the household are aggregated to produce a single capital input. The aggregate capital good is denoted by $H_{t}$ and is produced according to the Cobb-Douglas production function

$$
H_{t}=\left(\prod_{m=1}^{M} \gamma_{m}{ }^{-\gamma_{m}}\right)\left(\prod_{m=1}^{M}\left(K_{t}^{m}\right)^{\gamma_{m}}\right) .
$$

We assume that $\sum_{m=1}^{M} \gamma_{m}=1$ so the production of the aggregate capital good has constant returns to scale. Firms that produce the capital aggregate sell the aggregate good for a rental price $R_{t}$ and pay type-specific rental prices $R_{t}^{m}$. Each period these firms choose a combination of type-specific capital inputs $\left\{K_{t}^{m}\right\}_{m=1}^{M}$ to maximize profits

$$
R_{t} H_{t}-\sum_{m=1}^{M} R_{t}^{m} K_{t}^{m}
$$

subject to the production function (16). The first order condition for the choice of $K_{t}^{m}$ is

$$
R_{t} \gamma_{m} \frac{H_{t}}{K_{t}^{m}}=R_{t}^{m}
$$

The scalar term $\prod_{m=1}^{M} \gamma_{m}^{-\gamma_{m}}$ in (16) ensures that the rental price for the capital aggregate is a weighted average of the rental prices of the type-specific rental prices. In equilibrium profits are zero for these firms.

The Numeraire Good. The numeraire good can be used either as the final consumption good, government purchases, payment for purchases of imported capital goods or as material input for the capital goods industries. The numeraire good is produced with aggregate capital $h_{t}^{Q}$, labor

\footnotetext{
${ }^{12}$ If the distribution tax were to remain constant over time (as we assume in the analysis below), then the taxadjusted user cost expression in the steady state is given by equation 3 . That is, the distribution tax cancels from the first-order condition under the "new view" of dividend taxation.
} 
$n_{t}^{Q}$ and effort $e_{t}^{Q}$. The output elasticity of effort is given by the parameter $\theta$. The production function for the numeraire good is

$$
Q_{t}=A\left[h_{t}^{Q}\right]^{\alpha}\left[\left(e_{t}^{Q}\right)^{\theta} n_{t}^{Q}\right]^{1-\alpha} .
$$

The producers of the numeraire good rent capital and labor and choose effort to maximize their discounted profits

$$
E_{t}\left[\sum_{j=0}^{\infty} \beta^{j} C_{t+j}^{-\frac{1}{\sigma}}\left[Q_{t+j}-W_{t+j}^{Q} n_{t+j}^{Q}-R_{t+j} h_{t+j}^{Q}-\frac{\xi^{n}}{2} n_{t+j-1}^{Q}\left(\frac{n_{t+j}^{Q}-n_{t+j-1}^{Q}}{n_{t+j-1}^{Q}}\right)^{2}-\frac{\xi^{h}}{2} h_{t+j-1}^{Q}\left(\frac{h_{t+j}^{Q}-h_{t+j-1}^{Q}}{h_{t+j-1}^{Q}}\right)^{2}\right]\right\}
$$

subject to the production function (19) and the wage-effort supply schedule (12). The parameters $\xi^{n}$ and $\xi^{h}$ are adjustment cost parameters for labor and capital. It is important to note that in a multi-sector model adjustment costs act through two distinct channels: they temper both the intertemporal substitution and the reallocation of capital and labor inputs across sectors.

Firms may ask workers to provide additional effort but doing so requires a higher wage. Note that, as long as the elasticity of effort in production is below unity $(\theta<1)$, the firm's demand for additional effort will be bounded. Another interpretation of effort input, which is effectively equivalent with the specification we adopt in this paper, is overtime to extend the work week. In this case, the elasticity of effort $\theta$ represents the shift premium households require to compensate them for working outside standard work hours. Including effort as a separate input allows measured TFP to increase in response to investment tax incentives, as it does in the data. This simple specification imparts realism to the model, but as we show in Section VI below, it remains somewhat limited in its ability to match the magnitude of the measured response of TFP in our reduced-form estimates.

The solution to the firm's optimization problem requires the following first order conditions,

$$
\begin{gathered}
\xi^{h}\left(\frac{h_{t}^{Q}-h_{t-1}^{Q}}{h_{t-1}^{Q}}\right)=\left[\alpha \frac{Q_{t}}{h_{t}^{Q}}-R_{t}\right]+\beta E_{t}\left[\left(\frac{C_{t+1}}{C_{t}}\right)^{-\frac{1}{\sigma}} \frac{\xi^{h}}{2}\left(\frac{h_{t+1}^{Q}-h_{t}^{Q}}{h_{t}^{Q}}\right)\left(\frac{h_{t+1}^{Q}+h_{t}^{Q}}{h_{t}^{Q}}\right)\right], \\
\xi^{n}\left(\frac{n_{t}^{Q}-n_{t-1}^{Q}}{n_{t-1}^{Q}}\right)=\left[(1-\alpha) \frac{Q_{t}}{n_{t}^{Q}}-W_{t}^{Q}\right]+\beta E_{t}\left[\left(\frac{C_{t+1}}{C_{t}}\right)^{\frac{1}{\sigma}} \frac{\xi^{n}}{2}\left(\frac{n_{t+1}^{Q}-n_{t}^{Q}}{n_{t}^{Q}}\right)\left(\frac{n_{t+1}^{Q}+n_{t}^{Q}}{n_{t}^{Q}}\right),\right.
\end{gathered}
$$


and

$$
\psi n_{t}^{Q}=C_{t}^{-\frac{1}{\sigma}}\left(1-\tau^{N}\right) \theta(1-\alpha) \frac{Q_{t}}{e_{t}^{Q}} .
$$

Equations (21) and (22) are the firm's intertemporal demand curves for capital and labor respectively. Equation (23) gives the firm's demand for effort. This condition says that the firm's choice of effort balances the after-tax marginal benefit of additional effort (the left-hand-side) with the marginal cost of additional effort (the right-hand-side). Not surprisingly, demand for effort is an increasing function of the marginal product of labor.

Domestic Capital Producers. Each type of capital is produced with units of the capital aggregate $h_{t}^{m}$, labor $n_{t}^{m}$, effort $e_{t}^{m}$ and materials $x_{t}^{m}$ (units of the numeraire good). The production function for each type of capital is

$$
I_{t}^{m}=B^{m}\left\{\mu_{x}\left(x_{t}^{m}\right)^{\frac{\rho-1}{\rho}}+\left(1-\mu_{x}\right)\left[\left(h_{t}^{m}\right)^{\mu_{h}}\left(e_{t}^{m}\right)^{\theta\left(1-\mu_{h}\right)}\left(n_{t}^{m}\right)^{\left(1-\mu_{h}\right)}\right]^{\frac{\rho-1}{\rho}}\right\}^{\frac{\rho}{\rho-1}}
$$

where $B^{m}$ is a scalar and the parameter $\mu_{x}$ governs the share of materials in production. The capital producers maximize the expected discounted value of profits,

$$
E_{t}\left[\sum_{j=0}^{\infty} \beta^{j} C_{t+j}^{-\frac{1}{\sigma}}\left\{P_{t+j}^{m} I_{t+j}^{m}-W_{t+j}^{m} n_{t+j}^{m}-x_{t}^{m}-\frac{\xi^{n}}{2} n_{t+j-1}^{m}\left(\frac{n_{t+j}^{m}-n_{t+j-1}^{m}}{n_{t+j-1}^{m}}\right)^{2}-\frac{\xi^{h}}{2} h_{t+j-1}^{m}\left(\frac{h_{t+j}^{m}-h_{t+j-1}^{m}}{h_{t+j-1}^{m}}\right)^{2}\right]\right]
$$

The first order conditions for the optimal choices of $x_{t}^{m}, n_{t}^{m}, h_{t}^{m}$ and $e_{t}^{m}$ are

$$
\begin{gathered}
1=P_{t}^{m} \mu_{x}\left(B^{m}\right)^{\frac{\rho-1}{\rho}}\left(\frac{I_{t}^{m}}{x_{t}^{m}}\right)^{\frac{1}{\rho}}, \\
\xi^{n}\left(\frac{n_{t}^{m}-n_{t-1}^{m}}{n_{t-1}^{m}}\right)=\left[P_{t}^{m} M P_{t}^{n, m}-W_{t}^{m}\right]+\beta E_{t}\left[\left(\frac{C_{t+1}}{C_{t}}\right)^{-\frac{1}{\sigma}} \frac{\xi^{n}}{2}\left(\frac{n_{t+1}^{m}-n_{t}^{m}}{n_{t}^{m}}\right)\left(\frac{n_{t+1}^{m}+n_{t}^{m}}{n_{t}^{m}}\right)\right], \\
\xi^{h\left(\frac{h_{t}^{m}-h_{t-1}^{m}}{h_{t-1}^{m}}\right)}=\left[P_{t}^{m} M P_{t}^{h, m}-R_{t}\right]+\beta E_{t}\left[\left(\frac{C_{t+1}}{C_{t}}\right)^{-\frac{1}{\sigma}} \frac{\xi^{h}}{2}\left(\frac{h_{t+1}^{m}-h_{t}^{m}}{h_{t}^{m}}\right)\left(\frac{h_{t+1}^{m}+h_{t}^{m}}{h_{t}^{m}}\right)\right],
\end{gathered}
$$


and

$$
\psi n_{t}^{m}=C_{t}^{-\frac{1}{\sigma}}\left(1-\tau^{N}\right) \theta(1-\mu) \frac{P_{t}^{m} I_{t}^{m}}{e_{t}^{m}}
$$

The marginal product of capital and the marginal product of labor are given by

$$
M P_{t}^{m, h} \equiv \mu_{h}\left(1-\mu_{x}\right)\left(B^{m}\right)^{\frac{\rho-1}{\rho}}\left(\frac{I_{t}^{m}}{U_{t}^{m}}\right)^{\frac{1}{\rho}} \frac{U_{t}^{m}}{h_{t}^{m}},
$$

and

$$
M P_{t}^{m, n} \equiv\left(1-\mu_{h}\right)\left(1-\mu_{x}\right)\left(B^{m}\right)^{\frac{\rho-1}{\rho}}\left(\frac{I_{t}^{m}}{U_{t}^{m}}\right)^{\frac{1}{\rho}} \frac{U_{t}^{m}}{n_{t}^{m}},
$$

where $U_{t}^{m} \equiv\left(h_{t}^{m}\right)^{\mu_{h}}\left(e_{t}^{m}\right)^{\theta\left(1-\mu_{h}\right)}\left(n_{t}^{m}\right)^{\left(1-\mu_{h}\right)}$. Equations (26), (27) and (28) are the firm's demand curves for materials, labor hours and the aggregate capital input, respectively. Equation (29), which is analogous to (23), is the firm's effort demand curve.

Imported Capital. To avoid having to specify the rest of the world in detail, we model the international trade margin with an investment import supply curve. We assume that in the initial non-stochastic steady state, there are no imported capital goods. The parametric form for the import supply curve is

$$
I M P_{t}^{m}=\bar{I}^{m}\left[\left(\frac{P_{t}^{m}}{P^{m}}\right)^{\chi}-1\right]
$$

where $\bar{I}^{m}$ is the amount of type $m$ capital produced in the steady state and $\chi$ is the import supply elasticity. If $\chi=0$ then the model collapses to a closed economy with no interaction with foreign capital importers. If $\chi=\infty$ then the model becomes a "small open economy" with regard to the capital goods markets. In this latter case, the domestic price of capital goods will be pinned down by the import prices.

Trade Balance. For simplicity and transparency, we assume period-by-period trade balance, so exports of the numeraire good increase to balance imports of equipment goods and vice versa. Our analysis-focused on a relatively small equipment goods sector-has little to say about the extent to which international borrowing and lending changes in response to fiscal shocks. Instead, Appendix E presents a variant of the model that allows for different extents of 
international borrowing and lending and allows us to evaluate the robustness of our findings with respect to the behavior of the trade balance across time.

\section{Resource Constraints and Real GDP}

The total amount of the numeraire good is used for either consumption of the final good, materials inputs for the capital producers, government purchases or payment for imported capital goods from abroad. The resource constraint for the numeraire good is

$$
Q_{t}=C_{t}+X_{t}+\sum_{m=1}^{M} P_{t}^{m} I M P_{t}^{m}+G_{t} .
$$

Aggregate capital and materials must satisfy

$$
H_{t}=h_{t}^{Q}+\sum_{m=1}^{M} h_{t}^{m}
$$

and

$$
X_{t}=\sum_{m=1}^{M} x_{t}^{m} .
$$

Real gross domestic product (GDP) is the sum of all final goods and services produced in a given period evaluated at the steady state pre-tax prices. We let $Y_{t}$ denote real GDP. Thus,

$$
Y_{t}=C_{t}+\sum_{m=1}^{M} P^{m}\left[I_{t}^{m}+I M P_{t}^{m}\right]+G_{t} .
$$

Note that $I_{t}^{m}+I M P_{t}^{m}$ is total investment purchases (production plus imports). Because the model assumes period-by-period balanced trade, there is no net export term in (36). While equipment can be imported, equal exports of the numeraire good are offered in exchange.

\section{Exogenous Processes}

To close the model, we need to specify the stochastic process for the tax policy variables. This plays two roles in the analysis below. First, we need an empirical process for the estimation of structural parameters. Second, we consider alternative processes for simulating the effects of tax policies. Let

$$
\Xi_{t}=\left[\tau_{t}^{\pi}, \zeta_{t}^{1}, \ldots, \zeta_{t}^{M}\right]^{\prime}
$$


denote the vector of exogenous tax variables at date $t$ where $\tau_{t}^{\pi}$ is the tax rate for corporate profits and $\zeta_{t}^{m}$ is the comprehensive investment tax subsidy for type $m$ capital. We assume that the law of motion for $\Xi_{t}$ is given by

$$
\Xi_{t}=\bar{\Xi}_{t}+\tilde{\Xi}_{t}
$$

where $\tilde{\Xi}_{t}=\left[\tilde{\tau}_{t}^{\pi}, \tilde{\zeta}_{t}^{1}, \ldots, \tilde{\zeta}_{t}^{M}\right]^{\prime}$ is the percent deviation of the tax variables from a time varying trend $\bar{\Xi}_{t}$. We assume that $\tilde{\Xi}_{t}$ follows a VAR process

$$
\tilde{\Xi}_{t}=\Lambda \tilde{\Xi}_{t-1}+\boldsymbol{\varepsilon}_{t},
$$

where $\boldsymbol{\varepsilon}_{t}$ is a date- $t$ vector of structural innovations and $E\left[\boldsymbol{\varepsilon} \boldsymbol{\varepsilon}^{\prime}\right]=\Omega$ is a variance-covariance matrix.

For the indirect inference estimation, we assume that $\Lambda$ is diagonal with an autoregressive root $\lambda<1$ that is equal across types of capital. The time varying trend $\bar{\Xi}_{t}$ is a step function with a single break occurring at the 1986 tax reform. Hence, $\bar{\Xi}_{t \leq 1986}$ is set equal to the average value of the tax variables prior to 1986 and, $\bar{\Xi}_{t>1986}$ is set equal to the average value of the tax variables after 1986. Thus, agents perceive the majority of the changes in investment subsidies as being transitory. The exception to this is the 1986 tax change which is interpreted as an unanticipated, permanent change. Hence, in the simulations, the tax vector $\Xi_{t}$ experiences a one-time, unanticipated shift in 1986. Given this specification of shocks, for any given $\lambda$ we choose the sequence of vectors of structural tax shocks $\boldsymbol{\varepsilon}_{t}$ to exactly match the observed time paths of the tax rates and investment subsidies, and feed them into the simulations used for the indirect inference.

\section{E. Steady State and Calibrated Parameters}

Non-Stochastic Steady State. We choose the scaling parameters $\phi, \psi$ and $B^{m}=B$ to ensure that $P^{m}=P=N=e=1$ in the non-stochastic steady state. Without loss of generality, we express steady state investment in type $m$ capital in proportion to type 1 . It is easy to show that $I^{m}=\Psi^{m} I^{1}$ where the scaling factors $\Psi^{m}$ are

$$
\Psi^{m}=\frac{\gamma_{m} \delta^{m}}{\gamma_{1} \delta^{1}}\left(\frac{r+\delta^{1}}{r+\delta^{m}}\right)\left(\frac{1-\zeta^{1}}{1-\zeta^{m}}\right)
$$


Additionally, $n^{m}=\Psi^{m} n^{1}$ and $x^{m}=\Psi^{m} x^{1}$ so there is a constant material-to-labor ratio across investment sectors. Similarly, $K^{m}=\left(\delta^{m} / \delta^{1}\right) \Psi^{m} K^{1}$ and $h^{m}=\Psi^{m} h^{1}$ for all $m$. Additional details on the steady state solution can be found in Appendix C.

Baseline Calibration. Most of the parameters are calibrated to standard values used in the macroeconomic literature on DSGE models. In this subsection, we focus on parameters that are important to the baseline, but not pivotal for the margins of adjustment that are the focus of the analysis. Table 5.A summarizes the baseline values for the calibrated parameters used in the model that are constant across all model simulations. We set the quarterly discount factor $\beta$ to 0.99 which implies a 4 percent annual real interest rate. The Frisch labor supply elasticity $\eta$ is set to 0.5, in line with recent estimates (see Farber 2005 and Kimball and Shapiro 2008). We set $\sigma$, the elasticity of intertemporal substitution, to 0.2 , roughly the average of the estimates in Hall (1988), Campbell and Mankiw (1989) and Barsky, et al. (1997). Based on calculations in House and Shapiro (2008), we set the steady state tax rates to $\tau^{N}=0.36, \tau^{d}=0.30$ and $\tau^{\pi}=0.43$ (the tax rate on corporate profits is a time series average of marginal tax rates taken over the sample period).

To calibrate labor's share for the numeraire $(Q)$ sector, we take total employee compensation as a fraction of total GDP less proprietors' income. This share has been roughly constant in the post-war period and, using data up to 2009, implies $1-\alpha=0.62 .^{13}$ This calculation implicitly assumes that proprietors' income is divided proportionally between labor income and capital income.

The model has $M=50$ different types of capital. There are 30 equipment classes and 20 structures classes. (The model includes all types of capital, while the reduced-form estimates exclude computers, software, and residential types.) Together with data on average investment shares ( $\left.I^{m} / I^{1}\right)$ and average investment subsidies $\left(\zeta^{m}\right)$ we use equation (39) to calculate implied values for $\gamma_{m}$. Tables $1 \mathrm{~A}$ and $1 \mathrm{~B}$ lists the capital classes in the model together with their associated depreciation rates, investment shares (as a fraction of total investment) and their average investment subsidies over the sample period.

\footnotetext{
${ }^{13}$ See Elsby et al. (2013) for a discussion of recent changes to the U.S. labor's share.
} 
To calibrate the share parameters $\mu_{h}$ and $\mu_{x}$ we use data on input shares from the NBER productivity dataset. We use the same parameters for structures as for equipment though we have no independent input data for structures to verify our calibration. Relative to labor's share for GDP, labor's share of gross investment output (for equipment production) is quite low and has been falling over the sample period. Averaging over all of the types in our data, labor's share in capital producing industries fell from roughly 20 percent in the late 1960's to roughly 9 percent by 2009. For purposes of calibrating the model we assume that labor's share of gross output in the capital-producing sectors is 14 percent (roughly the average over all types and time periods). Material's share of gross output is approximately 45 percent. ${ }^{14}$ The implied capital share in gross output $\left(R h^{m} / I^{m}\right)$ is $1-0.14-0.45=0.41$. In steady state, $R h^{m} / W n^{m}=\mu_{h} /\left(1-\mu_{h}\right)$. Using

$$
\frac{R h^{m}}{W n^{m}}=\frac{0.41}{0.14}=2.93
$$

implies that $\mu_{h}=0.75$. We calibrate the parameter $\mu_{x}$ to match the observed materials ratio $X^{m} / I^{m}$ given the elasticity of substitution $\rho$. In the steady state,

$$
\mu_{x}=\left(1+\left(M C^{U}\right)^{\frac{1-\rho}{\rho}}\left(\frac{I^{m}}{X^{m}}-1\right)^{\frac{1}{\rho}}\right)^{-1}
$$

Where $M C^{U} \equiv\left(1-\mu_{h}\right)^{\mu_{h}-1}\left(\mu_{h}\right)^{-\mu_{h}} W^{1-\mu_{h}} R^{\mu_{h}}$ is the “marginal cost” of $U^{m}$. For each substitution parameter $\rho$, we set $\mu_{x}$ according to (41) to match a materials-to-investment ratio $X^{m} / I^{m}=0.45$. For our baseline calibration we set $\rho=0.01$, which implies that there is essentially no substitution between materials and the input composite $U_{t}^{m}$ (for this value of $\rho$, the implied calibration for $\mu_{x}$ is extremely small). ${ }^{15}$

Calibrations Affecting Domestic Adjustment. Several parameters directly affect the elasticity of domestic supply. Because of how they interact with the estimated import supply elasticity, we

\footnotetext{
${ }^{14}$ We include energy in total material inputs. Energy is a very small fraction of gross investment output, roughly 1 percent.

${ }^{15}$ If we estimate the materials substitution elasticity $(\rho)$ the estimates are pushed to 0.00 . We suspect this reflects the fact that there is a high degree of correlation between production and materials throughout the data sample. This estimate echoes a recent finding by Boehm et al. (2014). See also Atalay (2014).
} 
will consider estimates of model parameters under alternative calibrations of these parameters. Table 5.B shows the baseline and alternative values of these parameters.

The labor and capital adjustment cost parameters $\xi^{n}$ and $\xi^{h}$ are calibrated using combined evidence from several different studies. Caballero and Engel (1993) use data on gross and net employment flows for U.S. manufacturing from the Bureau of Labor Statistics. They estimate an annual quadratic adjustment cost parameter of 0.53 for net flows and 0.28 for gross flows, although they prefer a specification with fixed costs. ${ }^{16}$ Shapiro (1986) estimates employment adjustment costs of $0.23-0.34$ for non-production workers, and zero for production workers. If we take 0.25 as a representative estimate, the corresponding quarterly adjustment cost is 1.0 (four times the annual value). We use $\xi^{n}=1.00$ as our baseline calibration.

There is a wide range of estimates of capital adjustment costs in the literature. For our baseline, we use a calibration with moderate adjustment costs-consistent with the moderate (Shapiro 1986) to low (Hall 2004) estimates in the literature. Specifically, we set $\xi^{h}=8.00$ for our quarterly model. Following the thought experiment in Hall (2004) this implies that the doubling time for capital in response to a permanent increase in its shadow value is roughly two years (8 quarters).

Given the relatively wide range of adjustment costs estimated in the literature, and that we specify a multi-sector model rather than a single sector like in most of these studies, we also consider how our results change if we adopt lower factor adjustment costs $\left(\xi^{n}=0\right.$ and $\xi^{h}=2$ ) and higher factor adjustment costs $\left(\xi^{n}=4.00\right.$ and $\left.\xi^{h}=16.00\right)$, which doubles the adjustment time.

The model allows for unobserved effort in production. The magnitude of this effect is captured by the production elasticity of effort $\theta$. In the model, $\theta$ must be between 0 and 1 . There are few reliable estimates of utilization elasticities that we can turn to. ${ }^{17}$ There are some estimates from the DSGE literature on reactions to identified monetary shocks, but these estimates are quite wide and are often estimated to be at on or the other corner of admissible

\footnotetext{
${ }^{16}$ Cooper and Willis (2009) use the empirical results of Caballero and Engel (1993) to estimate a set of structural models with asymmetric labor adjustment costs. Their estimates for the quadratic costs specification are 7.9 for positive adjustment and -0.28 for negative adjustment, however neither coefficient is statistically significant.

${ }_{17}$ The elasticity is identified by the derivative of the cost of increasing utilization (e.g., the shift premium or incremental depreciation). There are estimates of the level of this cost in the literature, but not of its derivative. We are grateful to Susanto Basu for a discussion of this issue.
} 
values. For our baseline calibration we will choose the intermediate value $\theta=0.5$ and consider how our estimates change for higher or lower values.

The final parameter governing the domestic supply of investment is $\psi_{n}$ which limits the long-run substitution of labor across sectors. $\psi_{n}=0$ implies that labor is perfectly substitutable across sectors in the long run. $\psi_{n}=\eta^{-1}=2$ implies that each sector has a separate labor supply curve with no possibility of substitution. Our baseline calibration of this parameter is to set $\psi_{n}=1.00$, with 0.25 and 1.75 as low and high alternatives.

Persistence of Tax Policy Changes. We also calibrate the (perceived) persistence of policy changes. This persistence is determined by the parameter $\lambda$ in the transition matrix in (38). If $\lambda$ is close to 1.00 then tax changes are perceived as permanent in the sense that agents believe that it is equally likely for tax subsidies to increase or decrease in the future. If $\lambda$ is less than 1.00 then agents interpret changes in tax policy as transitory events which are expected to be undone in the future. It is convenient to discuss this calibration when we discuss introducing the policy shocks into the estimation, so that discussion is deferred to the next section.

\section{F. Estimating the Supply Elasticity of Foreign Equipment}

Here we estimate the foreign supply elasticity of equipment $\chi$. This structural parameter is of central importance in determining the reactions of domestic production and domestic purchases of equipment to changes in investment tax subsidies. ${ }^{18}$ We use an indirect inference approach similar to the one proposed by Gourieroux, Montfort and Renault (1993). Given any value of $\chi$, we simulate the post-war investment paths implied by the model using the observed shocks to investment subsidies and tax rates as forcing variables. We then run regressions of the form (5) for the simulated data and recover the implied reduced-form coefficients. We choose the parameter $\chi$ to make the simulated regression coefficients and their reduced-form analogues match as closely as possible.

\footnotetext{
${ }^{18}$ We limit our attention to this parameter for several reasons. It is central for quantitatively distinguishing between production and purchases of capital goods. Moreover, it is sharply identified by the difference in the reduced-form response of production versus purchases to investment subsidies, which is the key empirical finding of the paper. Conversely, while we can estimate other model parameters and have done so in earlier version of this paper, the data and the model are not particularly informative vehicles for estimating them.
} 
Simulating the Path of Investment Subsidies in the Post-War Period. To implement the indirect inference, we simulate the model using variation in tax subsidies as the stochastic forcing variation. As is clear from Figure 4, there is substantial variation in tax subsidies both across types and over time (that is, relative to the numeriaire good). We do not include variation in productivity shocks as is conventional in DSGE modeling. ${ }^{19}$

Equation (38) describes the evolution of the exogenous forcing processes. We assume that the tax changes are perceived as autoregressive with common persistence across types, so $\Lambda=\operatorname{diag}(\lambda)$. We construct a path of shocks that generates the investment subsidies and tax rates observed over the time period of our data sample as

$$
\boldsymbol{\varepsilon}_{t}=\tilde{\Xi}_{t}-\Lambda \tilde{\Xi}_{t-1} .
$$

The subsidy and the tax rates are mechanically related to each other (recall (2) and (4)), so we include the exact path of both in the simulation. With the structural innovations, we can simulate the economy's dynamic reaction to the shocks. Note, we do not have to specify the covariance of the shocks. Instead, since we use the actual realization of the shocks in the estimation, the simulation exactly reflects the strong common movements of tax rates and investment subsidies.

We calibrate $\lambda$ to 0.9167 , which, in our quarterly model, corresponds to a three-year expected duration of tax changes. This expected duration is roughly in line with the evidence in Table 2 on the frequency of tax changes. The alternative values of 0.8750 and 0.9375 correspond to two and four-year expected durations. The expected duration of the investment subsidy powerfully affects how much it increases investment, with shorter durations leading to larger increases in investment as firms take advantage of the temporary reduction of the cost of durable investment. This parameter therefore has a considerable effect on the magnitude of response to a policy shock.

Indirect Inference. To implement the indirect inference, we simulate the path of endogenous variables given a value of $\chi$ and for the path of policy variables as just described. We estimate the reduced-form regressions (5) on the simulated data, which generates the model-implied moments. The indirect inference approach then adjusts the estimate of the model parameter to

\footnotetext{
${ }^{19}$ As long as technology shocks are uncorrelated with the tax subsidies, including them would not change the average simulated response that we are using for estimation.
} 
find the best fit of the model-implied moments with the analogous moments in the data (the "targeted moments"). Specifically, the targeted moments are the estimated coefficients on the comprehensive subsidy ( $b_{1}$ in equation 5 ) for five different regressions with the following lefthand-side variables: equipment production, equipment purchases, hours, material inputs, and measured productivity (TFP). ${ }^{20}$ Denote the vector of these $b_{1}$ estimates as $\hat{\mathbf{b}}^{\text {data }}$ and let $\mathbf{b}(\chi)$ denote the corresponding vector of regression coefficients for the model simulation given a vector of parameters $\chi \cdot{ }^{21}$ Our parameter estimate $\hat{\chi}$ is the solution to the minimum distance problem

$$
\hat{\chi}=\arg \min _{\chi}\left\{\left[\hat{\mathbf{b}}^{\text {data }}-\mathbf{b}(\chi)\right]^{\prime} \hat{\Omega}^{-1}\left[\hat{\mathbf{b}}^{\text {data }}-\mathbf{b}(\chi)\right]\right\}
$$

where $\Omega=\operatorname{Var}\left[\hat{\mathbf{b}}^{\text {data }}\right]$. Under the usual conditions, the estimate is asymptotically normally distributed $\hat{\chi} \sim N\left(\chi^{*}, \sigma_{\chi}^{2}\right)$. The estimated variance of the indirect inference estimate is

$$
\hat{\sigma}_{\chi}^{2}=\left[\left(\frac{\partial \mathbf{b}(\hat{\chi})}{\partial \chi}\right) \hat{\Omega}^{-1}\left(\frac{\partial \mathbf{b}(\hat{\chi})}{\partial \chi}\right)^{\prime}\right]^{-1} .
$$

Recall that $\hat{\Omega}$ accounts for heteroskedasticity and autocorrelation, so the estimated variance $\hat{\sigma}_{\chi}^{2}$ will also be heteroskedasticity and autocorrelation consistent.

Estimates of model parameters. The indirect inference estimates of the import supply elasticity $\chi$ are reported in Table 6 . The first column gives the targeted moments previously reported in the third column of Tables 3 and 4, i.e., the reduced-form regression coefficient of the response of the equipment production, equipment purchases, hours, materials, and TFP to the comprehensive subsidy for the "macro covariates" specification. The top row gives the estimates

\footnotetext{
${ }^{20}$ We target equipment production and purchases because their distinct behavior is central to our analysis of subsidies. We also target materials, TFP, and hours because they carry important information about domestic supply elasticity. We do not target wages because it is well understood that measured wage payments may not be allocative on a spot basis (see Basu and House 2017 and the references therein). While we do not target equipment prices and structures prices and quantities we do examine the fit of the model for these untargeted moments (see below).

${ }^{21}$ We use the estimates of $\hat{\mathbf{b}}^{\text {data }}$ from the "macro covariates" columns of Table 3 and 4 in the indirect inference. The trend, oil prices, and Nixon price controls are not generated in the simulations and do not enter as exogenous forcing variables in the model, so we do not attempt to match the coefficients on the control variables ( $\Gamma^{m}$ in equation 5).
} 
of the import elasticity for the baseline and various alternatives of the calibrated parameters. The rest of the table reports the model-implied moments given the estimated supply elasticity.

There are several noteworthy features of these estimates. First, the estimates for the import supply elasticity are substantial. For the baseline specification, the estimate is 6.53. Inelastic values are far outside of the confidence interval. These estimates suggest that the U.S. faces an elastic international supply of capital goods. While this estimate changes as we change the calibrated parameters, the estimated elasticity is always above 3.

Table 6 also reports the model implied moments for the parameter estimates. Overall the model does a reasonably good job of reproducing the broad features of domestic production of investment equipment. The model matches the key reduced-form finding, that the response of investment production is substantially less than the response of purchases. For the baseline specification and other specifications, the modeled reduced-form coefficients come very close to the 1.08 value in the data. It is instructive to see how the modeled coefficients vary under alternative calibrations.

Policy persistence. The persistence parameter $\lambda$ controls how much investment demand responds to a policy shock. The lower the persistence, the more demand increases to take advantage of the temporary subsidy. Since the size of the shocks is given by the history of actual policy, low $\lambda$ implies a bigger increase in investment and vice versa. These outcomes are apparent in the modeled reduced-form estimates (the value of 1.59 in the baseline increases to 1.73 in the low persistence parameterization and decrease to 1.45 in the high persistence parameterization). Implicitly, imports take up more or less of the gap between domestic demand and domestic production. Even though the low persistent calibration fits the equipment investment moment a bit better than the baseline, we prefer the baseline value of $\lambda$ because its half-life of three years fits our reading of the narrative a bit better than the shorter half-life implied by the low persistence. With the higher increase in demand corresponding to the lower persistence, the estimated import supply elasticity is higher. That is, the model must estimate more responsive imports to accommodate the observed shift in demand. 
Margins Affecting Domestic Supply Response. The other alternatives to the baseline shown in Table 6 relate to the elasticity of domestic supply. Higher or lower supply response to effort $(\theta)$ imply more or less responsive domestic supply. Higher adjustment costs imply less responsive domestic supply. Higher or lower sectoral labor supply specificity $\left(\psi_{n}\right)$ imply less or more responsive domestic supply. Varying these parameters has the expected effects on the modeled reduced-form coefficients and on the estimate of the supply elasticity.

Other moments. The estimated model does a good job of hitting the targeted moments for hours. There is slight undershooting in the data of the theoretically-mandated one-for-one movement of production and materials, perhaps because of measurement problems. The most substantial discrepancy is for TFP. In the data, measured TFP rises by 0.28 log points for a 1 percentage point investment subsidy. In the model, the effort margin generates a reaction in TFP but it is substantially smaller than the estimate from the actual data.

Non-targeted moments. The model generates predictions for moments that are not targeted in the indirect inference procedure. Appendix Table D.1 shows results. The model predicts substantially larger response of structures than seen in the data. Given that the model leaves out features that make it hard to have structures respond quickly (within a quarter in the model) such as time to plan and time to build, this miss is not surprising or troubling. Similarly, the model implies a larger short-run effect on wages than seen in the data, again presumably because it does include frictions that might keep spot wages from being non-allocative. On the other hand, the model does a remarkably good job of hitting non-targeted movements in prices of capital goods.

\section{Simulated RESPONSE to InVESTMENT Subsidies}

We now use the estimated model to quantify the effects of investment tax policies on macroeconomic activity. We consider a policy that returns the ITC to the pre-1986-reform level of 10 percent. Consistent with historical practice, the simulated ITC applies to equipment, but not structures. We consider various scenarios for the expected and actual duration of the policy. For each simulation, we report the effects of the policy on investment (both aggregate and by type), the prices of capital goods, imports of equipment goods and macroeconomic aggregates. The simulation is based on the baseline estimate and calibration as reported in Table 6 . 


\section{A. Temporary Subsidy with Uncertain Expiration (Baseline case)}

For our baseline policy simulation, we consider a policy where the ITC is temporarily set to 10 percent and will sunset with a known probability. In particular, we assume that the sunset is described by a Poisson process with a constant hazard rate per unit time. The hazard rate is chosen to imply an expected duration of 3 years, which corresponds to the baseline value of $\lambda$ used to generate the parameter estimates for the simulations. ${ }^{22}$

To simulate sample realizations of the policy with constant hazard of return to baseline, we can model the ITC as having an expected path given by an AR(1) as in (38) with the diagonal elements of $\Lambda$ given by $\lambda=1-(1 / 12)$ (implying an expected policy horizon of 12 quarters as long as the policy stays in effect). Each period the policy continues conveys news, so results in a shock to the subsidy relative to its expected path. Thus, each sample path will look like a constant subsidy while the policy is in effect followed by a sudden removal of the subsidy at a random point in time.

Figure 5 shows a set of impulse response paths for several variables in the model under this temporary investment subsidy scenario. The figure depicts a policy that happens to last exactly 3 years - the expected duration of the policy. Again, the exact duration of the policy is unknown at the date the subsidy is introduced and so, much like the policies facing firms in the real world, there is an important element of uncertainty in the simulated tax policy. Figure 5.A reports domestically-produced investment goods for all of the types in the model. The differential response of equipment and structures production can be seen clearly in the figure. Since all types of equipment receive the subsidy, production of all types expand. The expansion is limited by the factor adjustment costs initially, but gradually rises as the subsidy continues. Structures do not receive the subsidy. ${ }^{23}$ Production of business and residential structures contracts while the policy is in effect. The cost of producing investment goods has gone up for all types (wages, capital services, and the effective cost of material inputs all rise), so structures production falls. Notice that once the subsidy is removed in period 13, production in the equipment categories does not return to steady state immediately, but instead falls only gradually

\footnotetext{
${ }^{22}$ Mertens and Ravn (2012) show how differences in the anticipation, implementation lag, and duration of tax changes affects aggregate economic outcomes (see also Mertens and Ravn 2013). Our approach gives an alternative method for incorporating duration into a DGSE model.

${ }^{23}$ Residential structures get either business or household treatment depending on the form of tenancy. In the simulations, we presume residential treatment on the margin, so they get zero subsidy each period.
} 
over time. This is again due to the factor adjustment costs, which keep labor and capital in the equipment-producing sectors temporarily above steady state.

Figure 5.B displays the equilibrium real relative (pre-tax) prices of the capital goods. Again, the differences between equipment and structures are easy to identify. Equipment prices rise immediately and remain high for the duration of the policy. For long-lived capital goods (i.e., capital goods with low depreciation rates) the price increase is on the order of the subsidy itself (see House and Shapiro 2008). Prices fall for the structures. Factor inputs are still attached to these industries because of the adjustment costs and this puts downward pressure on prices while the inputs are gradually reallocated to other sectors.

Figure 5.C shows imported capital goods (total additions to capital for each type is the sum of the lines in the Figure 5.A and Figure 5.C). Obviously, there is no response for structures (the line at zero). Given the imports supply curve (32), the response of imported equipment is simply a scaled-up version of the price response where the scaling factor is the estimated import elasticity (6.53).

Finally, Figure 5.D reports the simulated time paths for GDP, aggregate employment, aggregate consumption, aggregate investment production, aggregate investment purchases, and aggregate investment imports. In the short run, the increased investment is supplied primarily by imports. Only after domestic industries have had the opportunity to respond by expanding their productive capacity does domestic production rise. Notice that despite the large subsidy, the aggregate effects on GDP, employment and consumption are relatively modest. GDP rises by only 0.9 percent by the end of the policy. Employment rises immediately; even though it has adjustment costs, its maximal response is on impact because of the greater quasi-fixity of capital. Investment is a relatively small share of total employment, the subsidy affects only a portion of investment, and much of the short term stimulus is transmitted to foreign rather than domestic firms. All of these features limit the aggregate stimulus from investment tax subsidies. ${ }^{24}$ Nonetheless, a one to two percent of GDP effect could be noticeable in aggregate time series and significant as a counter-cyclical policy.

\footnotetext{
${ }^{24}$ Note that aggregate consumption changes only slightly in response to the subsidy. Hence, relaxing the assumption of period-by-period balanced trade would not change the results appreciably.
} 


\section{B. Comparison with no trade case}

To illustrate the role of trade in the response of the economy to an investment tax subsidy, we compare the responses in the baseline case to a case where trade is shut down. Figure 6 shows the response of GDP, aggregate investment purchases, aggregate investment production, and aggregate imports of capital goods for the baseline specification and for the no trade case to the same temporary shock to investment subsidies illustrated in Figure 5. Because of the more elastic supply of investment goods in the baseline case with international trade, the response of purchases to the tax subsidy is substantially greater on impact in the our model than in the no trade specification. On impact, aggregate purchases of investment goods increase by 15 percent in our model versus 3 percent with no imports. The peak response at quarter 12 (the period before the temporary subsidy has its random termination) is also about 15 percent versus 5 percent for the no trade case. ${ }^{25}$

Interestingly, when the tax subsidy expires, there is a more rapid decline of purchases in our baseline model than in the no trade case. Domestic production has increased by approximately the same amount with and without trade. When the subsidy expires, this abovesteady-state capacity to produce equipment leads to exports of equipment. Production also remains high longer because of the ability to sell into international markets. Hence, the presence of an import margin attenuates the stimulus to the overall economy of temporary investment subsidies, but leads to incremental stimulus after the policy has expired.

\section{Temporary Subsidy with Alternative Expirations}

There are multiple ways to model temporary tax policies. The simulation in Figure 5 is a realistic depiction of actual tax policies recently adopted in the U.S. It combines two distinct effects- the temporary nature of the policy change and the unanticipated expiration of the policy. Here we present two alterative simulations that separate these effects. In Figure 7, we simulate a subsidy that follows an AR(1) process with the same autoregressive coefficient as used in the simulation

\footnotetext{
${ }^{25}$ Aggregate GDP increases substantially more in the baseline case with trade in equipment than in the no-trade alternative. Because of the assumption of period-by-period trade balance, exports of numeraire good expand to pay for the imports of equipment. This finding depends on our specification of period-by-period balanced trade. If there were international borrowing, the increase in exports of numeraire can be spread out over many periods, so GDP rises less immediately, but more later. Appendix E presents simulations under alternative degrees of international borrowing and lending. The degree of borrowing does affect the timing of aggregate GDP substantially, but has little effect on the paper's central results relating to investment production and purchases. See Appendix Figure E1. The central empirical finding of the paper, that production versus purchases of equipment move quite differently in response to tax subsidies has little bearing on the extent to which the resulting imports are finance by international borrowing.
} 
behind Figure 5. But, unlike Figure 5, the subsidy simply decays at the AR rate and thus gradually declines from $10 \%$ to zero. This simulation is instructive, but not realistic. The AR(1) phase out in Figure 7 and the Poisson expiration in Figure 5 have similar patterns during the first 12 quarters except with the AR(1) decay, the magnitudes of the responses are lower because the value of the subsidy is uniformly lower. In both cases, the responses build over time as the capacity to produce equipment gradually increases. Upon expiration of the subsidy (that occurs randomly in Figure 5 at quarter 12), the dynamics look similar, though without the sharp jump. In Figure 5, there is a protracted period of exports of capital goods once domestic production has expanded sufficiently and the subsidy has been removed.

Alternatively, Figure 8 shows a constant subsidy with known expiration date at three years from its onset. This case has precedent in actual policy where temporary investment incentives are not uncommon (e.g., bonus depreciation, at least as initially legislated). Because we have calibrated the Poisson hazard (Figure 5) and AR(1) decay rate (Figure 7) and the duration of the policy (Figure 8) to each have an expected duration of three years, each model features the same reaction for all endogenous variables in the period in which the policy is announced and put into effect (the impact period). After the first period, the simulated paths diverge with the known temporary subsidy in Figure 8 having larger effects than in the policy where the tax subsidy decays (Figure 7) or gets extended in expectation by a period (Figure 5). The known and increasingly impending expiration in Figure 8 creates an urgency to invest during the known period of the subsidy. This effect is also seen in the prices. With the known, temporary subsidy, they are higher uniformly.

\section{Permanent Subsidy}

Figure 9 displays the impulse responses for a permanent investment subsidy, that is, a change in the subsidy that is expected to be permanent and actually is so. (It also represents policies that are expected to be temporary, but where the subsequent policy symmetrically increases or decreases the subsidy so that the continuation has the same expected value as the current subsidy. Obviously, the simulated paths would change when the future subsidy actually changes.)

As in Figure 5, there are clearly identifiable differences between equipment and structures. There are several differences between the two figures that deserve emphasis. Notice that in the long run, production of structures increases even though it is not subsidized. This is due to the fact that the capital aggregate (16) is a Cobb-Douglas aggregate over all of the capital 
types in the model. As a result, if the subsidy encourages firms to increase the total number of units of medical equipment, it is indirectly encouraging firms to increase the total number of hospitals as well (though to a lesser degree). Also, the price responses are not as great as they were in the temporary subsidy. For the permanent subsidy, the policy is anticipated to have a long-run impact on the stock of subsidized equipment. Since the price reflects the present value of the after-tax marginal products of capital, the anticipated increase in the stock of capital implies lower future marginal products and thus relatively lower current prices. Under the temporary policy, the long-run impact on the stock of equipment was not affected as much and so the prices were comparatively high. Finally, the aggregate effects of the permanent subsidy are not as great. Under the permanent subsidy there is no urgency to purchase the capital goods while the subsidy is in place and thus the firms can wait to acquire the goods. This delayreflected in a smaller price increase-implies that the short-run increase in overall investment production and aggregate employment is somewhat smaller than with a temporary subsidy.

E. Elasticity of Domestic Supply of Investment Goods (Alternative Parameter Values) The less-than-infinite elasticity of investment supply is the key driver of the analysis. Our model features a number of margins of adjustment that allow domestic production to respond to subsidies. Of course, the main sources of the finite supply elasticity are the quasi-fixity of capital and the upward sloping supply of labor that are a feature of our DGSE model. These alone, however, will not make supply of investment goods very inelastic because the investment-goodsproducing sector is relatively small. So if factors of production are mobile across sectors, production of investment goods could increase in response to tax subsidies with little increase in price.

Factors of production are not, however, very mobile across sectors (Ramey and Shapiro 1998, 2001). Our DGSE model introduces two sources of frictions relating to factor mobility: quadratic costs of adjusting labor and capital and specificity in sectoral labor supply. Working in the opposite direction of increasing elasticity of investment supply, the model allows for an intensity-of-work margin modeled as variable effort. Figure 10 quantifies the importance of these features of the model by showing how different parameter value in the model for these margins of adjustment effect the aggregate outcomes relative to the baseline case. For this exercise, we return to the case of the temporary subsidy with uncertain expected duration. The baseline results are the same as in Figure 5 and 6. Reducing the adjustment cost parameters $\xi^{n}$ and $\xi^{h}$ from 
their baseline values ( 1 and 8 respectively) to 0 and 2 makes all aggregates more responsive to the subsidy. Reducing the labor specificity parameter $\psi^{n}$ from its baseline value of 1 to 0.25 , in contrast, has little effect. ${ }^{26}$ Eliminating the variable effort margin (by setting $\theta$ to approximately 0 ) in contrast considerably decreases the flexibility of domestic supply, so it reduces the expansion of purchase, production, and GDP.

\section{CONCLUSION}

Investment tax incentives are used both to encourage capital accumulation in the long run and to stimulate economic activity in the short run. This paper highlights the distinction between the purchase and production of capital goods affected by these tax incentives. It finds that, in response to typical changes in investment tax incentives, only part of the observed increase in investment is met by domestic production. A substantial fraction of the increase in investment demand is met by imports. While investment tax incentives do promote capital accumulation, their ability to stimulate aggregate economic activity-especially in the sectors producing the subsidized capital goods-is limited to an extent by "leakage" of the stimulus to foreign producers through imports of capital goods. Hence, the production versus purchases mechanism identified and quantified in this paper is important for understanding the effects of investment tax policy.

Goolsbee (1998) argued that the stimulative effects of investment tax subsidies might be limited because the supply of capital goods was relatively inelastic. The production versus purchases mechanism in our analysis is quite different from the one identified by Goolsbee where investment incentives bid up the prices of capital goods. In our mechanism, the bidding up of prices is limited by foreign supply. Indeed, we do not find evidence that investment subsidies much affect the prices of investment goods in our sample. Using vintage data and his original estimation period, we can partially reproduce the original findings reported by Goolsbee. Hence, the differences in our empirical results for prices reflect changes in the economy since his work and, to an extent, revisions of the data used in the earlier analysis.

How does the economy respond to investment tax subsidies? To answer this question, the paper presents an equilibrium analysis of investment tax incentives. To capture important

\footnotetext{
${ }^{26}$ For temporary policies, labor specificity has little effect on the simulated responses. It does have important effects for permanent policies.
} 
margins of adjustment across investment sectors and to include a distinction between domestic purchases and domestic production of capital goods, we specify a dynamic stochastic general equilibrium model with capital and labor adjustment costs, variable effort, and international trade in equipment. We estimate parameters of the model using indirect inference based on the reduced-form responses of production, purchases and inputs in the investment sector to investment tax subsidies.

The structural estimates indicate the import supply of equipment is quite elastic and thus the purchase/production distinction that is central to our analysis is quantitatively important. For typical changes in investment incentives, in the short run about half the increase in demand for investment is met by imports over the duration of the change. Moreover, because imports limit the increase in the price of investment goods, an investment tax incentive causes a greater increase in the stock of productive capital relative to an economy where all investment goods were produced domestically. On the other hand, production of domestic capital goods expands less than it would in an economy without international trade in capital goods, so the stimulus of domestic capital producers is less than it would be in the no-trade case during the period of the subsidy. Because capacity has increased, domestic producers export equipment following the expiration of the subsidy. 


\section{REFERENCES}

Abel, Andrew B. 1982. "Dynamic Effects of Permanent and Temporary Tax Policies in a q Model of Investment.” Journal of Monetary Economics 9(3): 353-373.

Atalay, Enghin. 2014. “How Important are Sectoral Shocks?” University of Chicago Working Paper.

Auerbach, Alan J., and Kevin A. Hassett. 1991. "Recent U.S. Investment Behavior and the Tax Reform Act of 1986: A Disaggregate View.” Carnegie-Rochester Conference Series on Public Policy 35: 185-215.

Auerbach, Alan J., and Kevin A. Hassett. 1992. “Tax Policy and Business Fixed Investment in the United States.” Journal of Public Economics 47(2): 141-170.

Bartelsman, Eric J., and Wayne B. Gray. 1996. “The NBER Manufacturing Productivity Database,” National Bureau of Economics Research Technical Working Paper 205.

Barsky, Robert B., F. Thomas Juster, Miles S. Kimball, and Matthew D. Shapiro. 1997. "Preference Parameters and Behavioral Heterogeneity: An Experimental Approach in the Health and Retirement Study.” Quarterly Journal of Economics 112(2): 537-579.

Boehm, Christoph, Aaron Flaaen, and Nitya Pandalai Nayar. 2014. "Input Linkages and the Transmission of Shocks: Firm-Level Evidence from the 2011 Tohoku Earthquake.” University of Michigan Working Paper.

Caballero, Ricardo, and Eduardo Engel. 1993. "Microeconomic Adjustment Hazards and Aggregate Dynamics.” The Quarterly Journal of Economics 108(2): 359-383.

Campbell, John, and Gregory N. Mankiw. 1989. "Consumption, Income and Interest Rates: Reinterpreting the Time Series Evidence.” NBER Macroeconomics Annual 4: 185-216.

Chirinko, Robert S., and Daniel J. Wilson. 2006. "State Investment Tax Incentives: What Are the Facts?” Federal Reserve Bank of San Francisco Working Paper 2006-49.

Chow, Gregory C., and An-loh Lin. 1971. "Best linear unbiased interpolation, distribution, and extrapolation of time series by related series.” The Review of Economics and Statistics (53): 372375.

Cooper, Russell, and Joao Ejarque. 2003. "Financial frictions and investment: requiem in q." Review of Economic Dynamics 6(4): 710-728.

Cooper, Russell, and Jonathan L. Willis. 2009. "The cost of labor adjustment: Inferences from the gap.” Review of Economic Dynamics 12(4): 632-647.

Cummins, Jason G., and Giovanni L. Violante. 2002. "Investment-Specific Technical Change in the US (1947-2000): Measurement and Macroeconomic Consequences." Review of Economic Dynamics 5(2): 243-284. 
Driscoll, John C., and Aart C. Kraay. 1998. "Consistent Covariance Matrix Estimation with Spatially Dependent Panel Data.” The Review of Economics and Statistics 80: 549-560.

Eberly, Janice, Sergio Rebelo, and Nicolas Vincent. 2008. “Investment and value: A neoclassical benchmark.” National Bureau of Economic Research Working Paper 13866.

Edgerton, Jesse. 2010. “Estimating Machinery Supply Elasticities Using Output Price Booms.” Federal Reserve Board Working Paper 2011-03.

Edgerton, Jesse. 2011. “The Effects of Taxation on Business Investment: New Evidence from Used Equipment.” Unpublished manuscript.

Elsby, Michael; Bart Hobijn, and Aysegul Sahin. 2013. "The Decline of the U.S. Labor Share.” Brookings Papers on Economic Activity 2013(2): 1-63.

Farber, Henry S. 2005. "Is Tomorrow Another Day? The Labor Supply of New York City Cab Drivers.” Journal of Political Economy 113(1): 46-82.

Feenstra, Robert C., John Romalis, and Peter K. Schott. 2002. "U.S.Imports, Exports and Tariff Data, 1989-2001.” National Bureau of Economic Research Working Paper 9387.

Fraumeni, Barbara M. 1997. "The Measurement of Depreciation in the U.S. National Income and Product Accounts.” Survey of Current Business July, 7-23.

Gilchrist, Simon, and Charles P. Himmelberg. 1995. "Evidence on the role of cash flow for investment.” Journal of Monetary Economics 36: 541-572.

Gomes, J., 2001. “Financing investment.” American Economic Review 91(5): 1263-1285.

Goolsbee, Austan. 1998. "Investment Tax Incentives, Prices, and the Supply of Capital Goods.” Quarterly Journal of Economics 113(1): 121-148.

Gordon, Robert J. 1990. The Measurement of Durable Goods Prices. Chicago: University of Chicago Press, Chicago, IL.

Gourieroux, Christian, Alain Monfort, and Eric Renault. 1993. “Indirect inference.” Journal of applied econometrics 8: S85-S85.

Gravelle, Jane H. 1994. The Economics Effects of Taxing Capital Income. MIT Press, Cambridge, MA.

Hall, Robert E., and Dale W. Jorgenson. 1967. “Tax Policy and Investment Behavior.” American Economic Review 57(3): 391-414.

Hall, Robert E. 1988. "Intertemporal Substitution in Consumption." Journal of Political Economy 96(2): 339-357. 
Hall, Robert E. 2004. "Measuring Factor Adjustment Costs." Quarterly Journal of Economics 119(3): 899-927.

Handbook, N.I.P.A. 2014. "Concepts and methods of the US national income and product accounts, Bureau of Economic Analysis.” http://www.bea.gov/methodologies/.

House, Christopher L., and Matthew Shapiro. 2008. "Temporary Investment Tax Incentives: Theory with Evidence from Bonus Depreciation.” American Economic Review 93(3): 737-768.

Hulten, Charles R., and Frank C Wykoff. 1981a. "The Estimation of Economic Depreciation Using Vintage Asset Prices: An Application of the Box-Cox Power Transformation.” Journal of Econometrics 15(3): 367-396.

Hulten, Charles R., and Frank C Wykoff. 1981b. “The Measurement of Economic Depreciation.” In Depreciation, Inflation, and the Taxation of Income from Capital, pp. 81-125. Washington, D.C: Urban Institute Press.

Jorgenson, Dale W. 1963. "Capital Theory and Investment Behavior." American Economic Review Papers and Proceedings 53(2): 247-259.

Jorgenson, Dale W., and Kun-Young Yun. 1990. “Tax Reform and U.S. Economic Growth.” Journal of Political Economy 98(5): S151-S193.

Jorgenson, Dale W., and Kun-Young Yun. 1991. Tax Reform and the Cost of Capital. Oxford: Oxford University Press.

Kimball, Miles, and Matthew D. Shapiro. 2008. "Labor Supply: Are Income and Substitution Effects Both Large or Both Small?” NBER Working Paper No. 14208.

Liu, Zheng, Daniel F. Waggoner, and Tao Zha. 2009. "Sources of the Great Moderation: Shocks, Friction, or Monetary Policy?” Federal Reserve Bank of San Francisco Working Paper 2009-01.

Mertens, Karel, and Morten O. Ravn. 2012. "Empirical Evidence on the Aggregate Effects of Anticipated and Unanticipated US Tax Policy Shocks.” American Economic Journal: Economic Policy 4(2): 145-81.

Mertens, Karel, and Morten O. Ravn. 2013. "The Dynamic Effects of Personal and Corporate Income Tax Changes in the United States.” American Economic Review 103(4): 1212-47.

Mussa, Michael L. 1977. "External and Internal Adjustment Costs and the Theory of Aggregate and Firm Investment.” Economica 44: 163-178.

Mian, Atif, and Amir Sufi. 2012. "The Effects of Fiscal Stimulus: Evidence from the 2009 'Cash for Clunkers’ Program.” Quarterly Journal of Economics 127 (3): 1107-1142.

Ramey, Valerie A., and Matthew D. Shapiro. 1998. "Costly Capital Reallocation and the Effects of Government Spending." Carnegie-Rochester Conference Series on Public Policy 48: 145194. 
Ramey, Valerie A., and Matthew D. Shapiro. 2001. "Displaced Capital: A Study of Aerospace Plant Closings.” Journal of Political Economy, 109: 958-992.

Romer, Christina D., and David H. Romer. 2009. "A Narrative Analysis of Postwar Tax Changes." Online appendix to Romer, Christina D., and David H. Romer. 2010. "The Macroeconomic Effects of Tax Changes: Estimates Based on a New Measure of Fiscal Shocks.” American Economic Review 100(3), 763-801.

Sallee, James M. 2011. "The Surprising Incidence of Tax Credits for the Toyota Prius." American Economic Journal: Economic Policy 3(2): 189-219.

Shapiro, Matthew D. 1986. “The Dynamic Demand for Capital and Labor.” Quarterly Journal of Economics 101: 513-542.

Sinn, Hans-Werner. 1991. "Taxation and the Cost of Capital: The "Old" View, the "New" View, and Another View," in Tax Policy and the Economy Vol 5, D. Bradford Ed., pp. 25-54. Cambridge MA: MIT Press.

Summers, Lawrence H. 1981. "Taxation and Corporate Investment: a q-Theory Approach.” Brookings Papers on Economic Activity 1981(1): 67-127.

U.S. Department of Commerce, Bureau of Economic Analysis. 1993. Fixed Reproducible Tangible Wealth in the United States: 1925-1989. Washington, DC: U. S. Government Printing Office.

Whelan, Karl. 1999. "Tax incentives, material inputs, and the supply curve for capital equipment.” Federal Reserve Board of Governors Working Paper 99-21.

Zwick, Eric, and James Mahon. 2017. “Tax Policy and Heterogeneous Investment Behavior.” American Economic Review 107(1): 217-48. 
FIGURE 1. EXPORTS AND IMPORTS OF CAPITAL EQUIPMENT, RELATIVE TO EQUIPMENT INVESTMENT

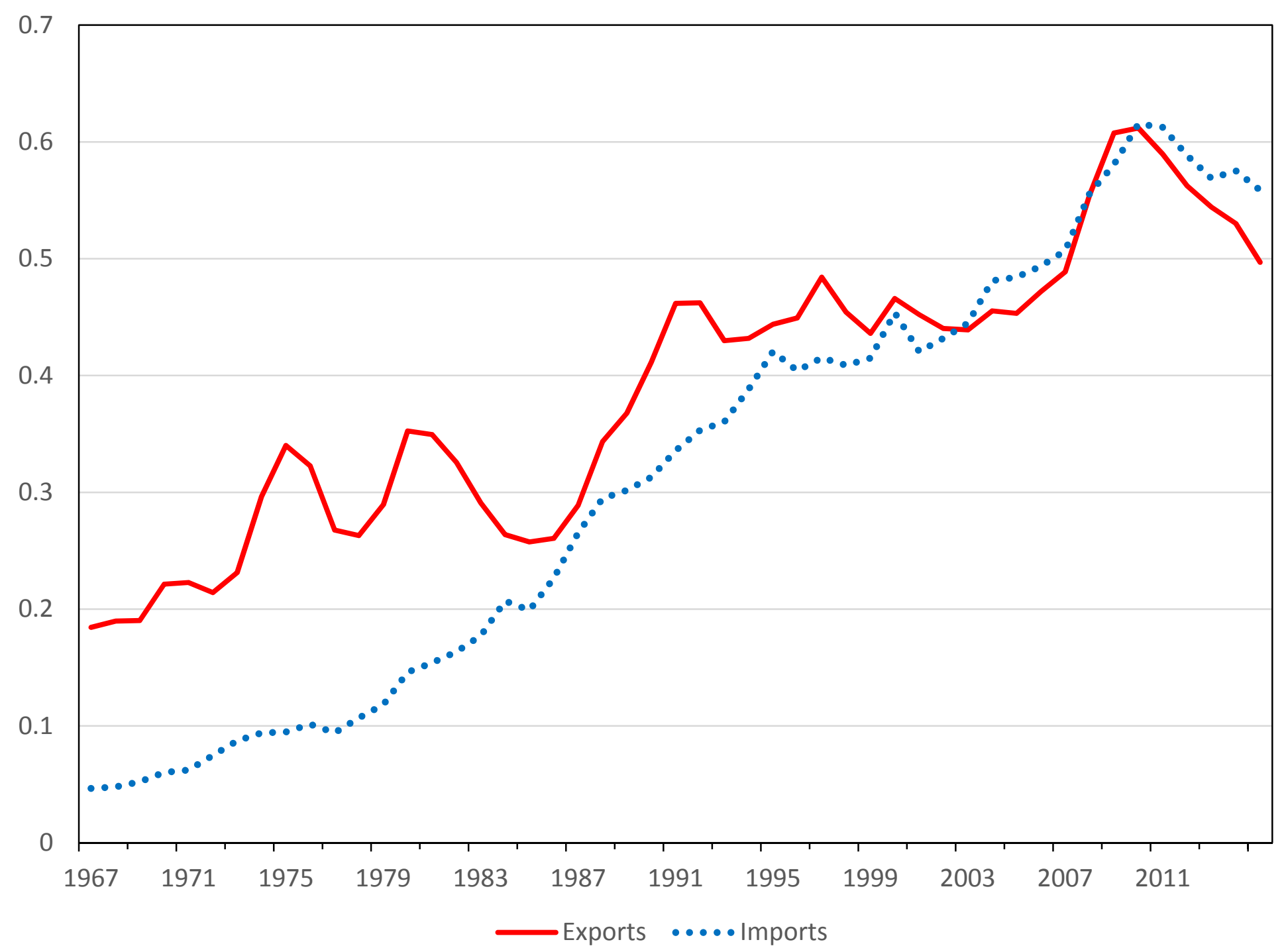


Figure 2. Purchases, Production ANd Prices, General Industrial EquiPMEnT (Log)

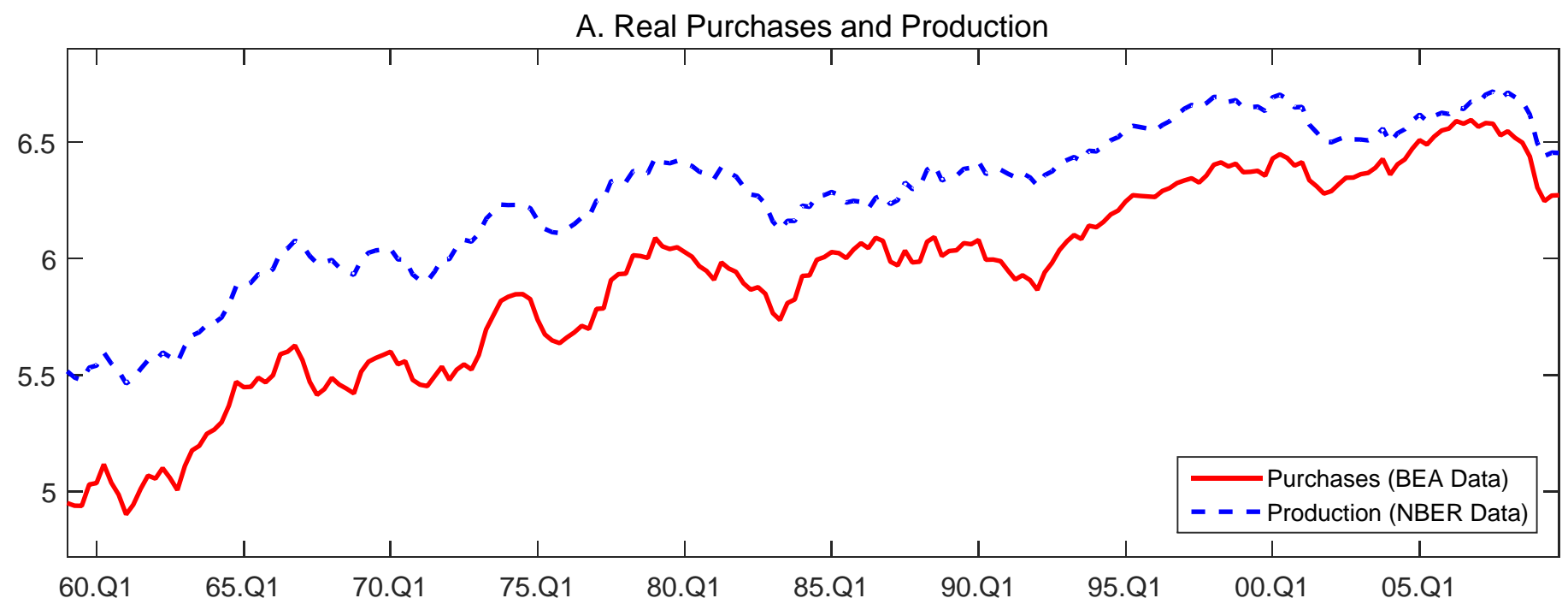

B. Real Prices

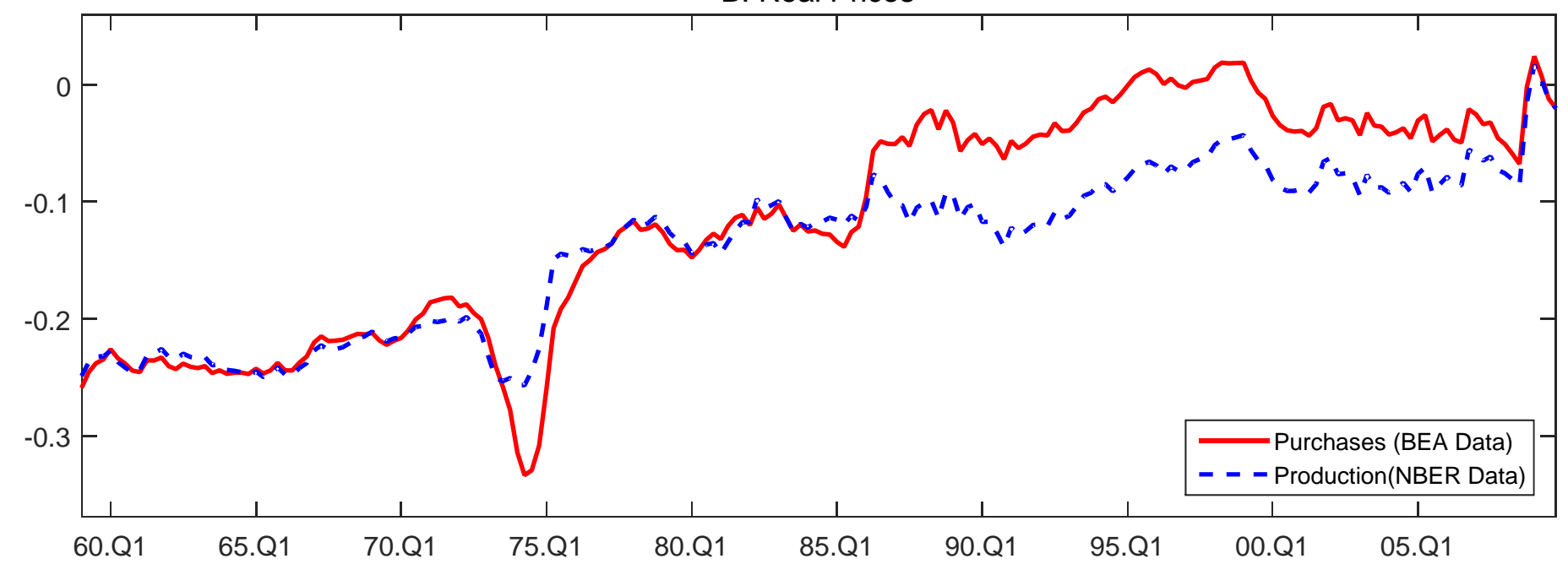


Figure 3. INVESTMENT SUBSIDY, GENERAL INDUSTRIAL EQUIPMENT

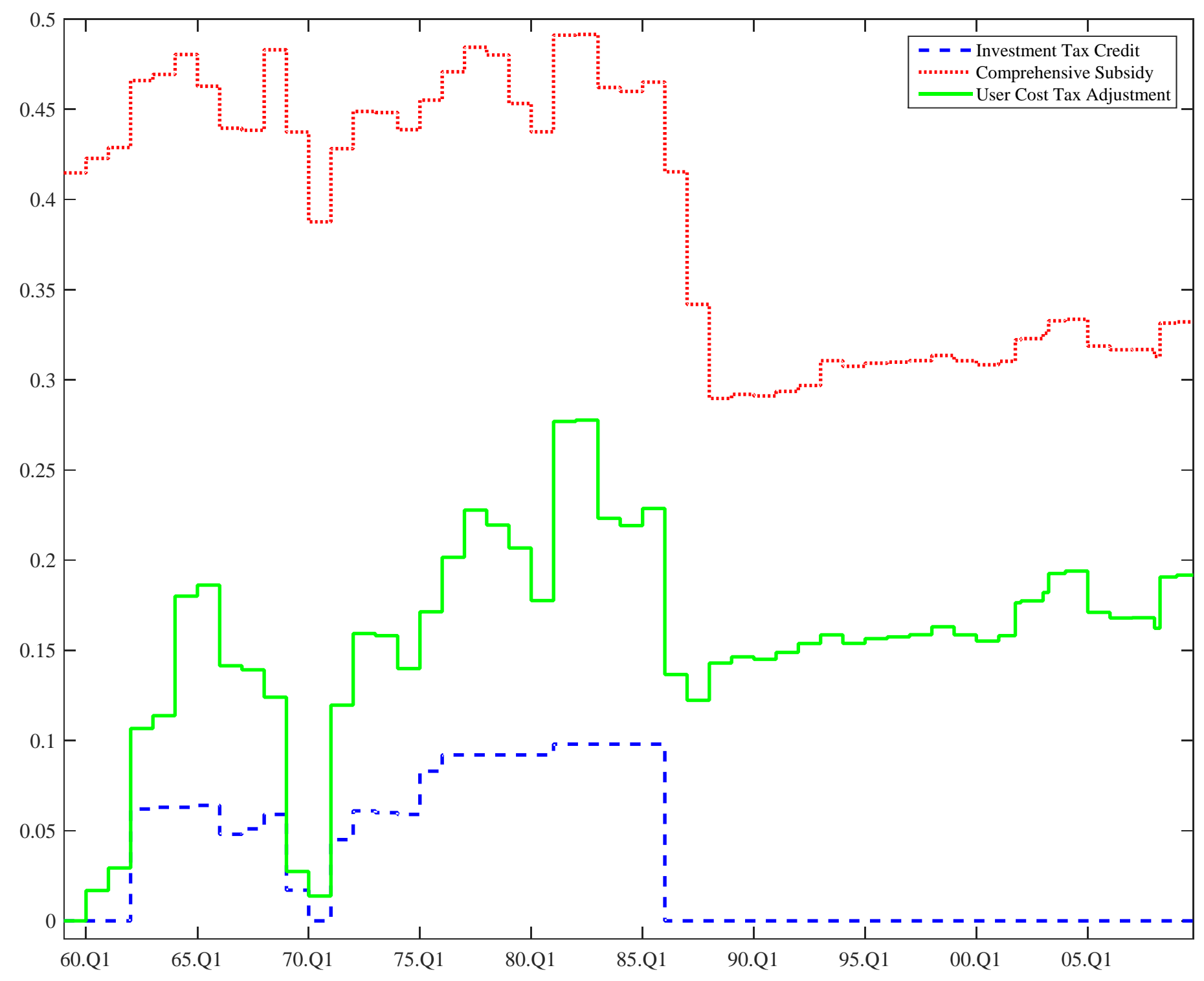


FiguRE 4. COMPREHENSIVE SUBSIDY By INVESTMENT TyPE

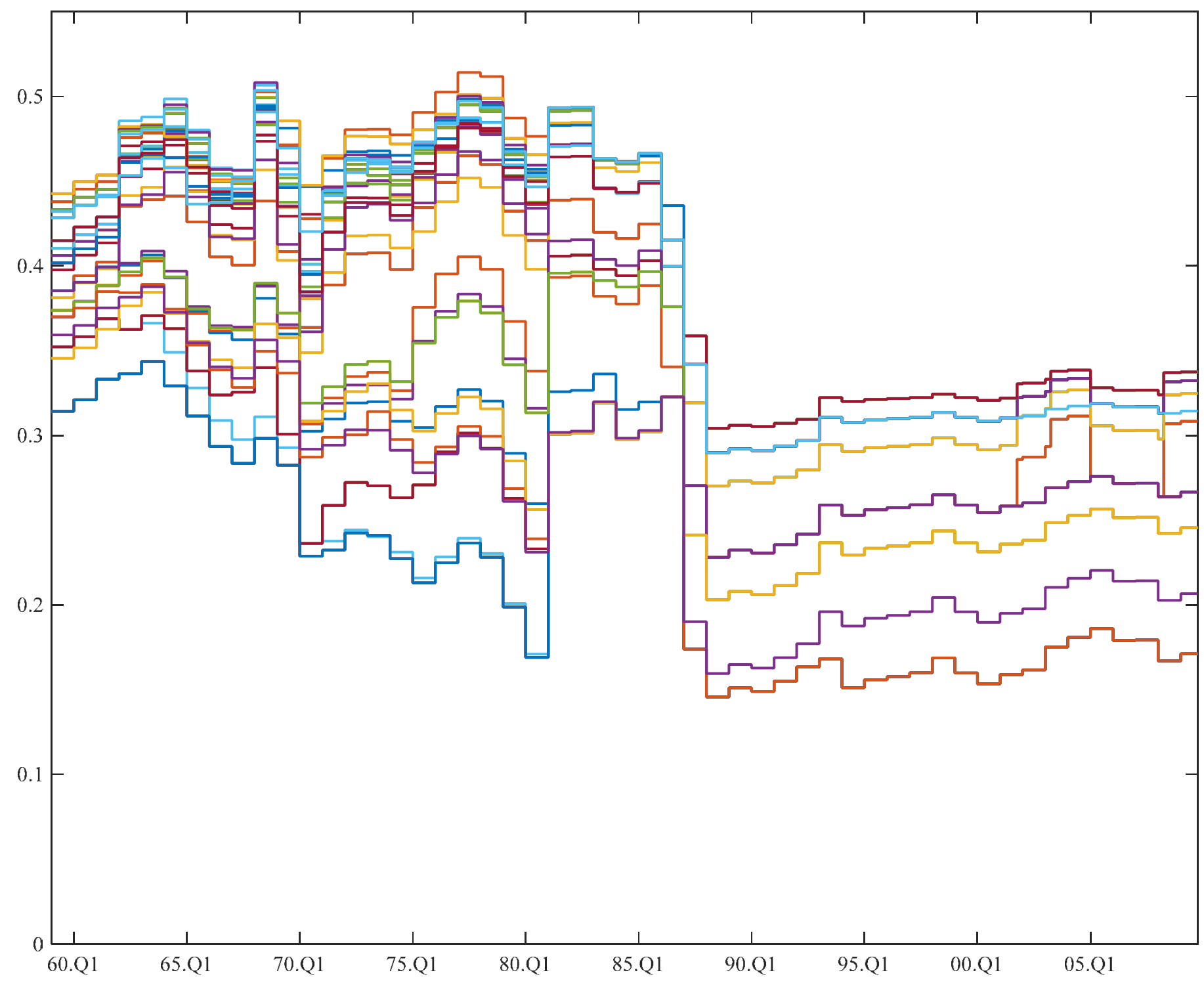


FIGURE 5. TEMPORARY INVESTMENT SUBSIDY FOR EQUIPMENT: UNCERTAIN EXPIRATION
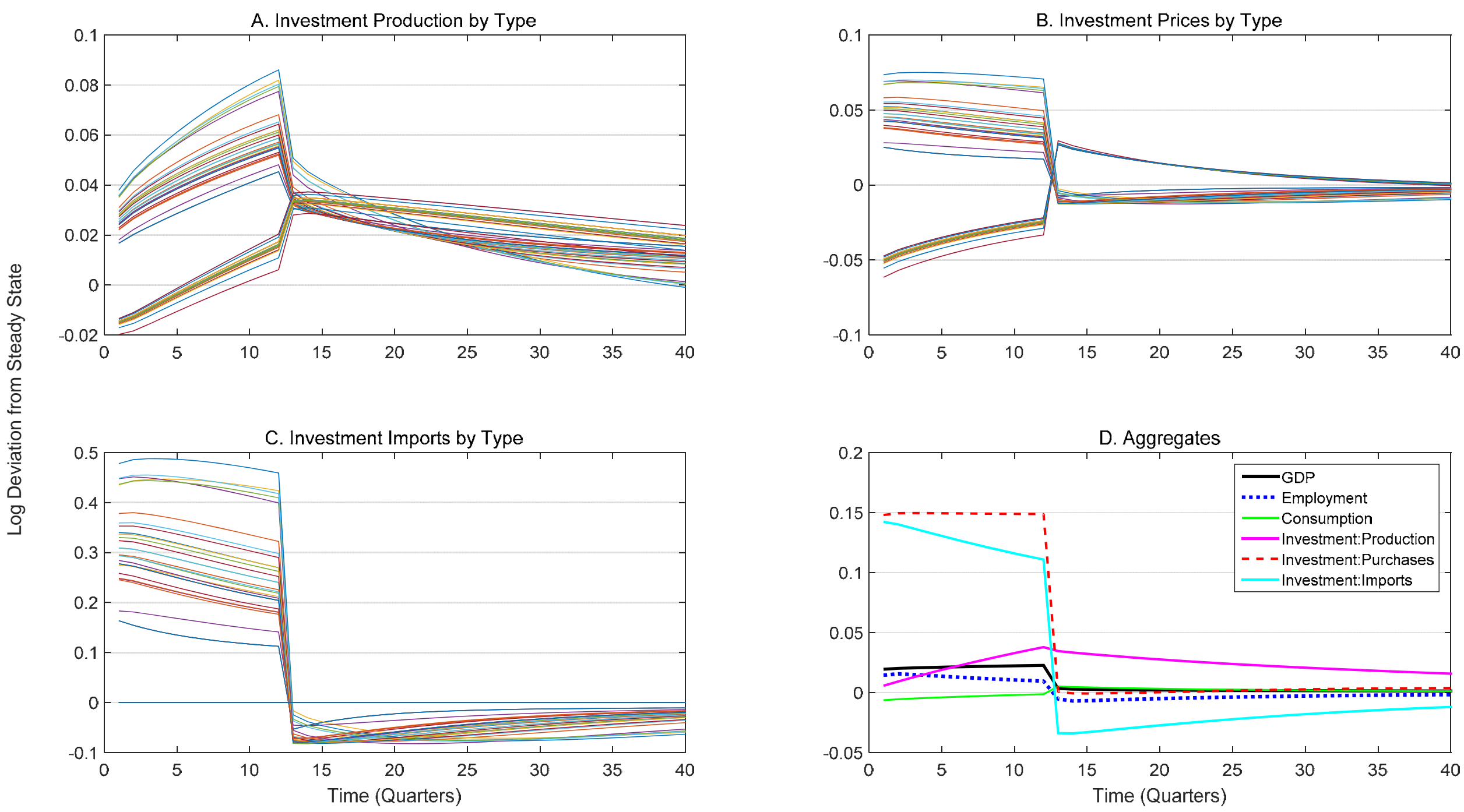

Notes: The figure reports the simulated impulse response functions for the selected variables. The investment subsidy is a 10 percent subsidy for equipment (structures are not eligible) and has an expected horizon of 3 years as described in the text. The figure plots a sample realization in which the policy sunsets in exactly 3 years. 
Figure 6. Aggregate Response to Temporary InVEstment Subsidy: Baseline Versus No Trade
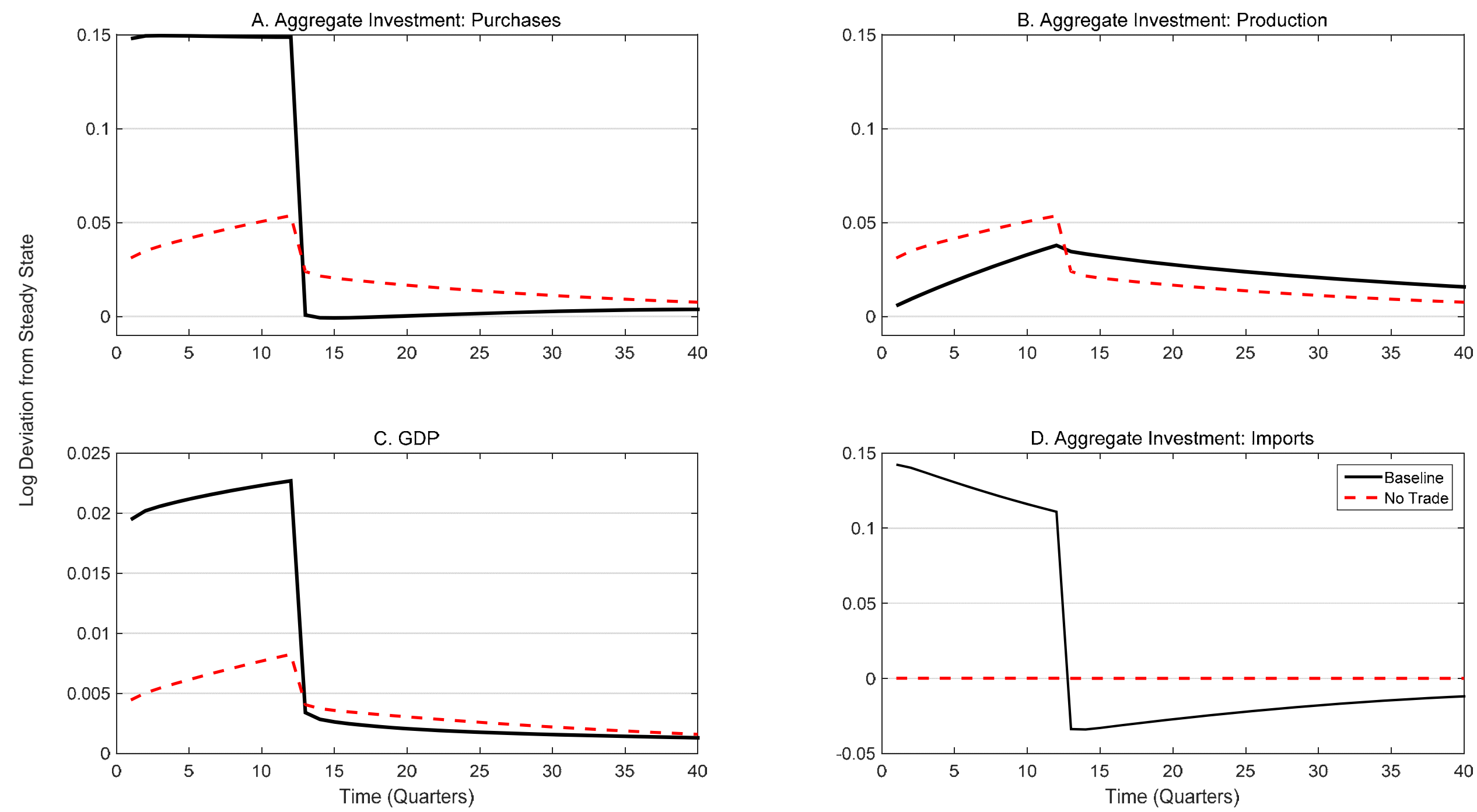

Notes: The figure reports the simulated impulse response functions for the selected variables. The policy experiment is identical to the one in Figure 4 . The solid line corresponds to the model with parameters set to the baseline simulation in Figure 4. The dashed line shows results for the model with no international trade. 
FIgURE 7. TEMPORARy InVESTMENT SUBSIDY FOR EquipMENT: AR(1) PHASE OUT
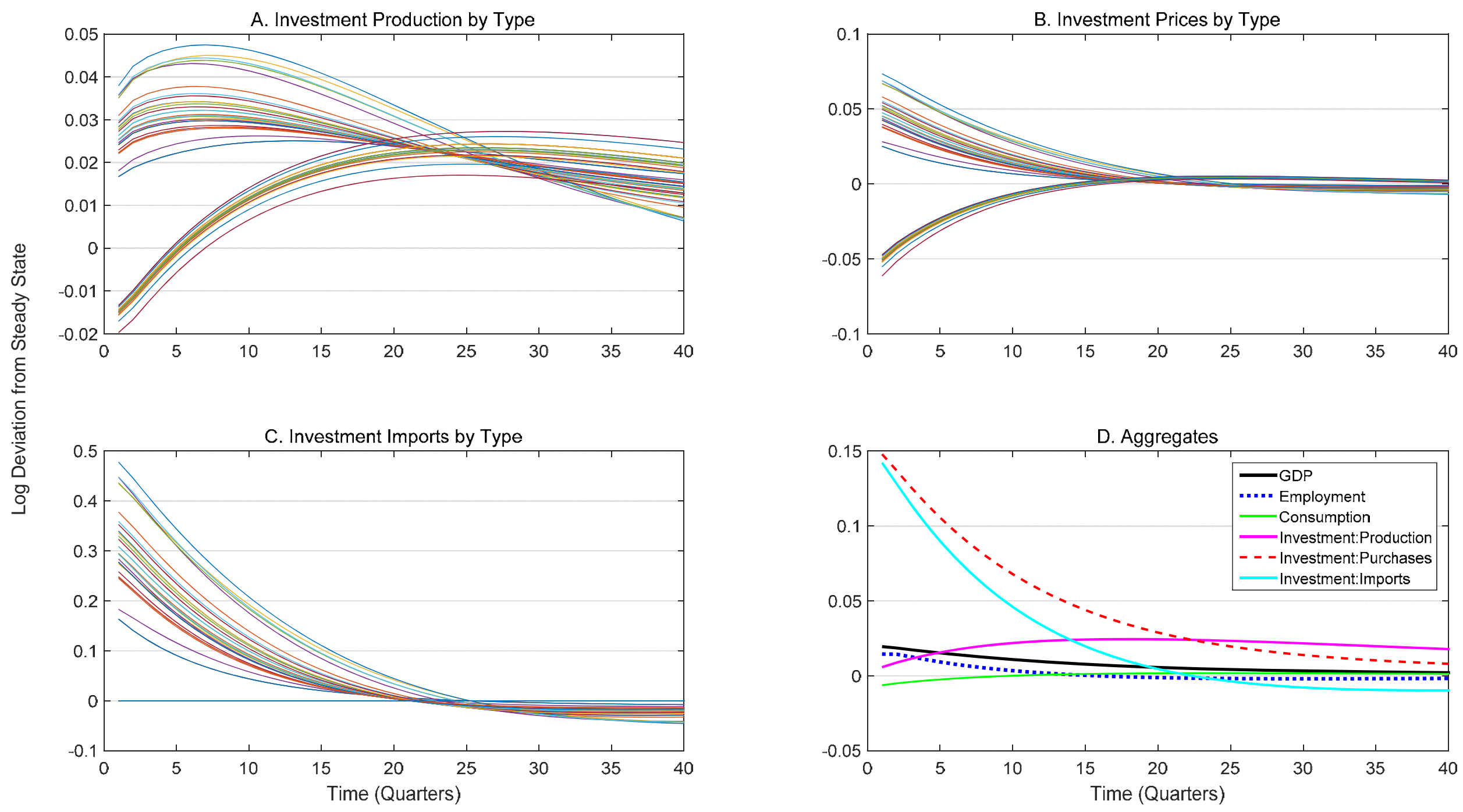

Notes: The figure reports the simulated impulse response functions for the selected variables. The investment subsidy is a 10 percent subsidy for equipment (structures are not eligible) and has an expected horizon of 3 years as described in the text. The figure plots a sample realization in which the policy sunsets in exactly 3 years. 
FIGURE 8. TEMPORARY INVESTMENT SUBSIDY FOR EQUIPMENT: KNOWN EXPIRATION
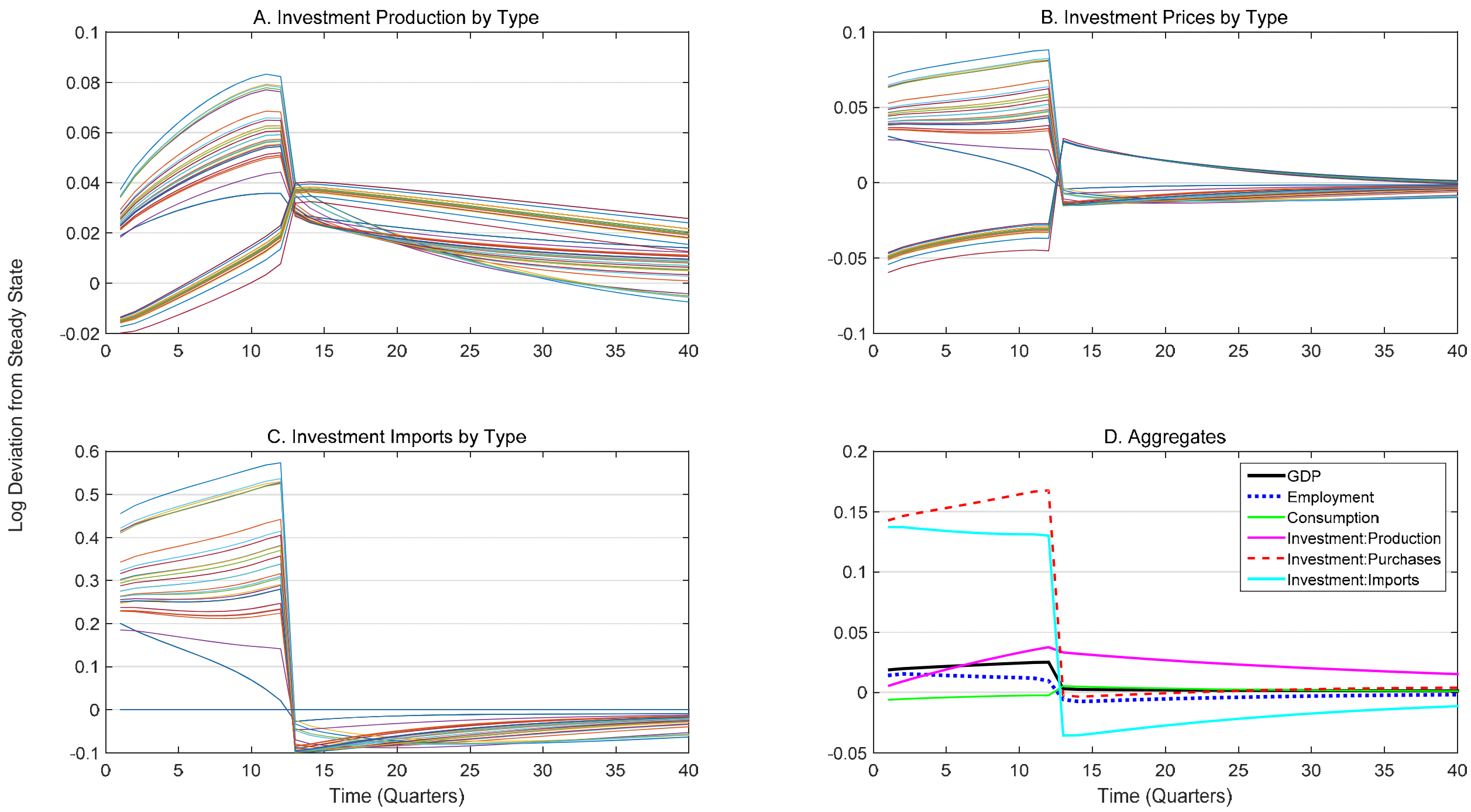

Notes: The figure reports the simulated impulse response functions for the selected variables. The investment subsidy is a 10 percent subsidy for equipment (structures are not eligible) and has an expected horizon of 3 years as described in the text. The figure plots a sample realization in which the policy sunsets in exactly 3 years. 
FIgURE 9. PERMANENT INVESTMENT SUBSIDY FOR EQUIPMENT
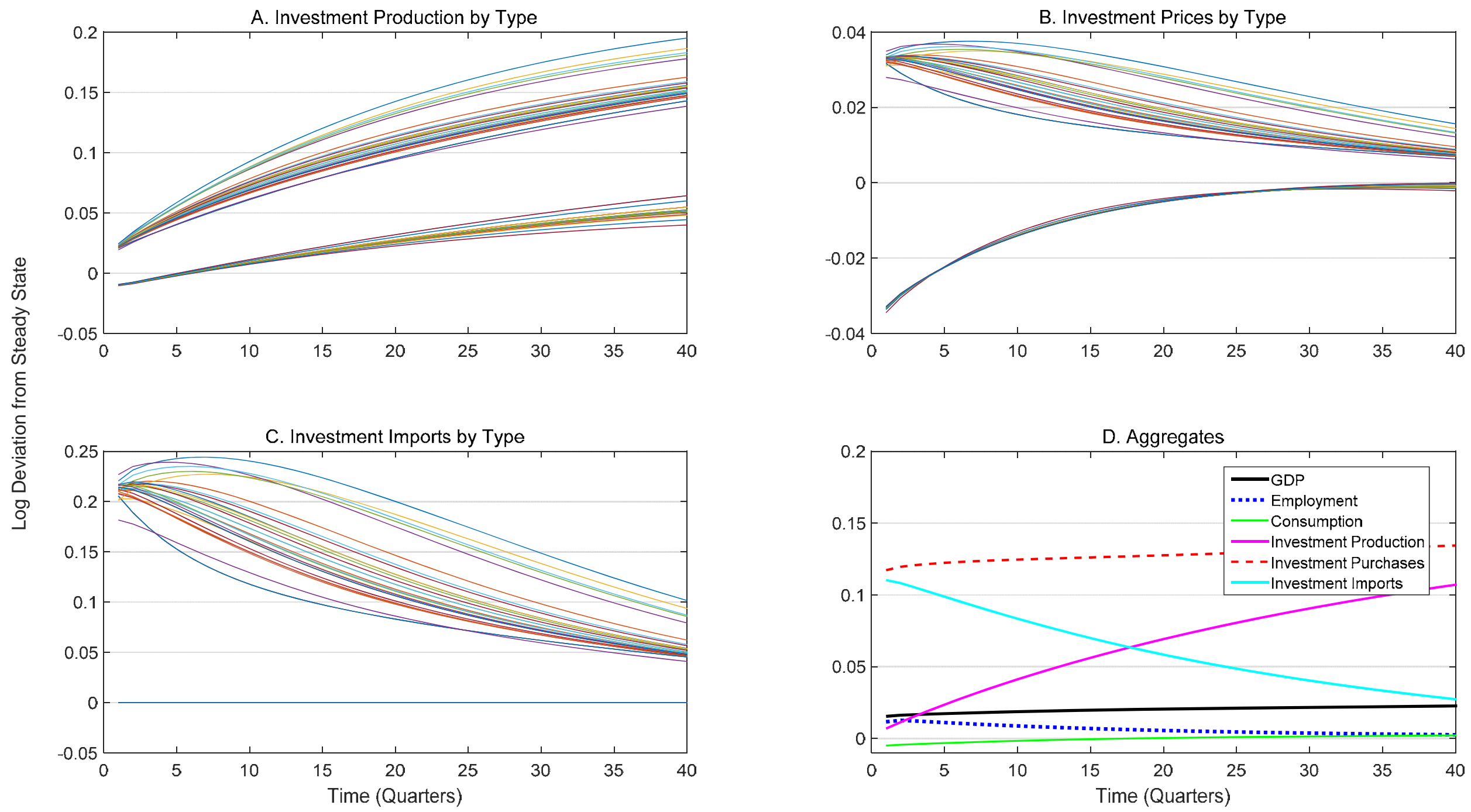

Notes: The figure reports the simulated impulse response functions for the selected variables. The investment policy is a permanent 10 percent subsidy for equipment (structures are not eligible). 
Figure 10. TEMPORARy InVESTMENT SUbSidy FOR EQUiPMENT: UnCERTAin EXPIRATIOn, Alternative PARAMETER VALUES
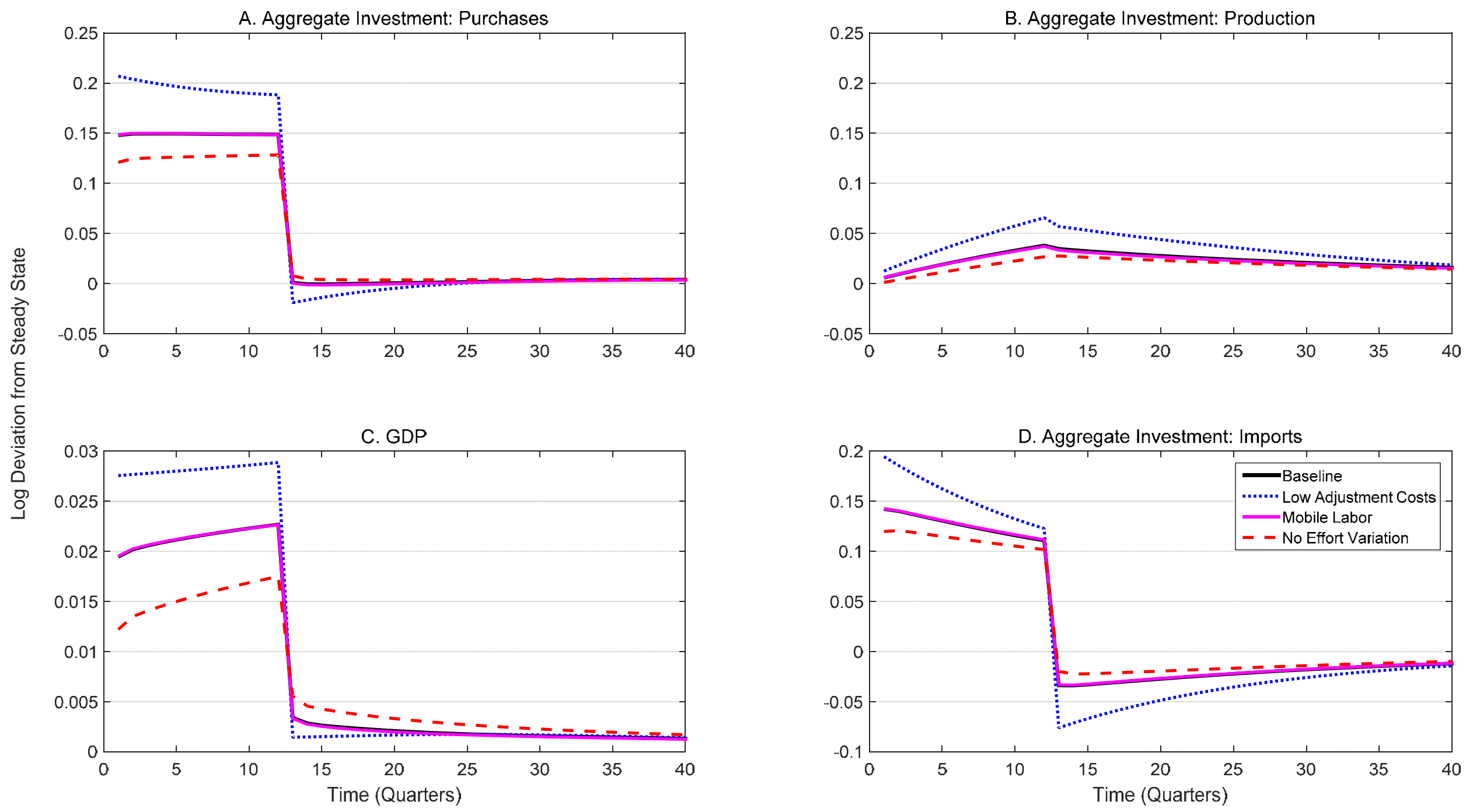

Notes: The figure reports the simulated impulse response functions for the selected variables. The investment subsidy is a 10 percent subsidy for equipment (structures are not eligible) and has an expected horizon of 3 years as described in the text. The figure plots a sample realization in which the policy sunsets in exactly 3 years. 
TABLE 1A. EQUiPMENT TYPES WITH DEPRECIATION RATES, INVESTMENT SHARES AND AVERAGE SUBSIDIES

\begin{tabular}{|c|c|c|c|}
\hline & $\begin{array}{c}\text { Depreciation } \\
(\delta)\end{array}$ & $\begin{array}{c}\text { Investment } \\
\text { Share }\end{array}$ & $\begin{array}{l}\text { Average } \\
\text { Subsidy }\end{array}$ \\
\hline Computers and peripheral equipment & 0.30 & $5.26 \%$ & 0.40 \\
\hline Software & 0.30 & $9.81 \%$ & 0.40 \\
\hline Communication equipment & 0.15 & $5.64 \%$ & 0.38 \\
\hline Electro-medical equipment & 0.18 & $1.10 \%$ & 0.39 \\
\hline Medical instruments & 0.14 & $1.53 \%$ & 0.39 \\
\hline Nonmedical instruments & 0.14 & $1.36 \%$ & 0.39 \\
\hline Photocopy and related equipment & 0.18 & $0.82 \%$ & 0.40 \\
\hline Office and accounting equipment & 0.30 & $0.43 \%$ & 0.40 \\
\hline Fabricated metal products & 0.09 & $0.92 \%$ & 0.39 \\
\hline Steam engines & 0.05 & $0.31 \%$ & 0.35 \\
\hline Internal combustion engines & 0.21 & $0.14 \%$ & 0.35 \\
\hline Metalworking machinery & 0.12 & $1.81 \%$ & 0.39 \\
\hline Special industrial equipment & 0.10 & $2.25 \%$ & 0.39 \\
\hline General industrial equipment & 0.11 & $3.26 \%$ & 0.39 \\
\hline Electrical transmission and distribution & 0.05 & $1.51 \%$ & 0.38 \\
\hline Trucks, buses, and truck trailers & 0.19 & $4.44 \%$ & 0.40 \\
\hline Autos & 0.17 & $2.84 \%$ & 0.40 \\
\hline Aircraft & 0.07 & $1.46 \%$ & 0.40 \\
\hline Ships and boats & 0.06 & $0.23 \%$ & 0.37 \\
\hline Railroad equipment & 0.06 & $0.41 \%$ & 0.38 \\
\hline Household furniture & 0.13 & $0.14 \%$ & 0.40 \\
\hline Other furniture & 0.12 & $2.16 \%$ & 0.40 \\
\hline Farm tractors & 0.15 & $0.42 \%$ & 0.39 \\
\hline Other agricultural machinery & 0.12 & $0.82 \%$ & 0.39 \\
\hline Construction tractors & 0.16 & $0.15 \%$ & 0.40 \\
\hline Other construction machinery & 0.16 & $1.32 \%$ & 0.40 \\
\hline Mining and oilfield machinery & 0.15 & $0.40 \%$ & 0.40 \\
\hline Service industry machinery & 0.17 & $1.29 \%$ & 0.40 \\
\hline Household appliances & 0.17 & $0.05 \%$ & 0.40 \\
\hline Miscellaneous electrical & 0.18 & $0.25 \%$ & 0.39 \\
\hline
\end{tabular}


TABLE 1B. STRUCTURES TYPES WITH DEPRECIATION RATES, INVESTMENT SHARES AND AVERAGE SUBSIDIES

\begin{tabular}{|c|c|c|c|}
\hline & $\begin{array}{c}\text { Depreciation } \\
(\delta)\end{array}$ & $\begin{array}{c}\text { Investment } \\
\text { Share }\end{array}$ & $\begin{array}{l}\text { Average } \\
\text { Subsidy }\end{array}$ \\
\hline Hospitals & 0.02 & $1.08 \%$ & 0.23 \\
\hline Special care & 0.02 & $0.25 \%$ & 0.23 \\
\hline Medical buildings & 0.02 & $0.39 \%$ & 0.23 \\
\hline Multi-merchandise shopping & 0.03 & $1.17 \%$ & 0.30 \\
\hline Food and beverage establishments & 0.03 & $0.55 \%$ & 0.30 \\
\hline Warehouses & 0.02 & $0.76 \%$ & 0.23 \\
\hline Other commercial structures & 0.03 & $1.04 \%$ & 0.30 \\
\hline Warehouses & 0.03 & $2.62 \%$ & 0.26 \\
\hline Manufacturing & 0.02 & $1.63 \%$ & 0.31 \\
\hline Electric & 0.02 & $0.58 \%$ & 0.31 \\
\hline Other power structures & 0.02 & $1.10 \%$ & 0.32 \\
\hline Communication & 0.08 & $2.38 \%$ & 0.31 \\
\hline Mining & 0.05 & $0.18 \%$ & 0.39 \\
\hline Religious structures & 0.02 & $0.44 \%$ & 0.23 \\
\hline Educational structures & 0.02 & $0.75 \%$ & 0.23 \\
\hline Railroads & 0.02 & $0.37 \%$ & 0.25 \\
\hline Farm structures & 0.02 & $0.33 \%$ & 0.29 \\
\hline Single-family structures & 0.01 & $15.21 \%$ & $\mathrm{n} / \mathrm{a}^{\mathrm{a}}$ \\
\hline Multifamily structures & 0.01 & $1.93 \%$ & $\mathrm{n} / \mathrm{a}^{\mathrm{a}}$ \\
\hline Other residential structures & 0.01 & $14.75 \%$ & $\mathrm{n} / \mathrm{a}^{\mathrm{a}}$ \\
\hline
\end{tabular}

\footnotetext{
${ }^{\mathrm{a}}$ In the United States, residential structures get either business and household treatment depending on the tenancy.
} For business treatment, the average business tax subsidy is 0.26 ; for residential treatment, it is zero. 
TABLE 2. LEgISLATIVE HistoRy OF INVESTMENT TAX INCENTIVES

\begin{tabular}{|c|c|c|c|c|c|}
\hline Law Name & $\begin{array}{l}\text { Public } \\
\text { Law No. }\end{array}$ & $\begin{array}{l}\text { Stated } \\
\text { Duration }\end{array}$ & $\begin{array}{l}\text { Actual } \\
\text { Duration }\end{array}$ & $\begin{array}{l}\text { Change to Investment } \\
\text { Tax Credit }\end{array}$ & $\begin{array}{l}\text { Change to Depreciation } \\
\text { Allowance }\end{array}$ \\
\hline Internal Revenue Code of 1954 & $83-591$ & Permanent & 4 years & & Double-declining balance method \\
\hline $\begin{array}{l}\text { Small Business Investment Act } \\
\text { of } 1958\end{array}$ & $85-699$ & Permanent & 4 years & & $\begin{array}{l}\text { First-year depreciation for long-lived } \\
\text { assets }\end{array}$ \\
\hline $\begin{array}{l}\text { Tax Rate Extension Act of } \\
1962\end{array}$ & $87-507$ & Permanent & 1.6 years & $\begin{array}{l}\text { Public utilities eligible for } \\
3 \% \text { ITC }\end{array}$ & \\
\hline Revenue Act of 1962 & $87-834$ & Permanent & 1.6 years & $\begin{array}{l}\text { Introduced 7\% ITC; } \\
\text { Limited for short-lived } \\
\text { assets; Public utilities } \\
\text { excluded }\end{array}$ & $\begin{array}{l}\text { Long Amendment (100\% basis } \\
\text { adjustment for ITC) }\end{array}$ \\
\hline Revenue Act of 1964 & $88-272$ & Permanent & 1.75 years & Simplified ITC & Removed basis adjustment \\
\hline $\begin{array}{l}\text { Suspension of Investment Tax } \\
\text { Credit of } 1966\end{array}$ & $89-800$ & $\begin{array}{l}\text { Temporary: } \\
1 \text { year }\end{array}$ & 0.6 years & Suspended ITC & Limited accelerated depreciation \\
\hline $\begin{array}{l}\text { Restoration of Investment Tax } \\
\text { Credit }\end{array}$ & $90-26$ & Permanent & 2.5 years & $\begin{array}{l}\text { Reinstated ITC and } \\
\text { increased ceiling }\end{array}$ & \\
\hline Tax Reform Act of 1969 & $91-172$ & Permanent & 1 year & Repealed ITC & \\
\hline $\begin{array}{l}\text { Reform of Depreciation Rules } \\
\text { (1971) }\end{array}$ & n.a. & Permanent & 0.9 years & & $\begin{array}{l}\text { Shortened the assumed life of } \\
\text { equipment and allowed more first year } \\
\text { depreciation }\end{array}$ \\
\hline
\end{tabular}




\begin{tabular}{|c|c|c|c|c|c|}
\hline Law Name & $\begin{array}{l}\text { Public } \\
\text { Law No. }\end{array}$ & $\begin{array}{l}\text { Stated } \\
\text { Duration }\end{array}$ & $\begin{array}{l}\text { Actual } \\
\text { Duration }\end{array}$ & $\begin{array}{l}\text { Change to Investment } \\
\text { Tax Credit }\end{array}$ & $\begin{array}{l}\text { Change to Depreciation } \\
\text { Allowance }\end{array}$ \\
\hline Revenue Act of 1971 & $92-178$ & Permanent & 3.25 years & $\begin{array}{l}\text { Restored ITC at } 7 \% \text {; } \\
\text { Limited for short-lived } \\
\text { assets; Public utilities } \\
\text { eligible for } 4 \%\end{array}$ & $\begin{array}{l}\text { Introduced ADR system } \\
\text { Lowered asset lifetimes }\end{array}$ \\
\hline Tax Reduction Act of 1975 & $94-12$ & Permanent & 1.6 years & $\begin{array}{l}\text { Increased to } 10 \% \text {; } \\
\text { Extended } 10 \% \text { ITC to } \\
\text { public utilities }\end{array}$ & \\
\hline Tax Reform Act of 1976 & $94-455$ & $\begin{array}{l}\text { Temporary: } \\
4.2 \text { years }\end{array}$ & 2.1 years & $\begin{array}{l}\text { Extended } 10 \% \text { ITC } \\
\text { through } 1980\end{array}$ & \\
\hline Revenue Act of 1978 & $95-600$ & Permanent & 2.75 years & $\begin{array}{l}\text { Made } 10 \% \text { ITC } \\
\text { permanent }\end{array}$ & \\
\hline $\begin{array}{l}\text { Economic Recovery Tax Act of } \\
1981\end{array}$ & $97-34$ & Permanent & 1 year & $\begin{array}{l}\text { Extended 10\% ITC to } \\
\text { short-lived assets }\end{array}$ & $\begin{array}{l}\text { Replaced ADR with ACRS; Simplified } \\
\text { asset-life classes; Introduced } \\
\text { Accelerated depreciation deductions }\end{array}$ \\
\hline $\begin{array}{l}\text { Tax Equity and Fiscal } \\
\text { Responsibility Act of } 1982\end{array}$ & $97-248$ & Permanent & 1.8 years & & Repealed accelerated depreciation \\
\hline Deficit Reduction Act of 1984 & $98-369$ & Permanent & 2.3 years & & $\begin{array}{l}\text { Lengthened asset lives from } 15 \text { years to } \\
18 \text { years }\end{array}$ \\
\hline Tax Reform Act of 1986 & $99-514$ & Permanent & 10.8 years & Repealed ITC & $\begin{array}{l}\text { Replaced ACRS with MACRS; } \\
\text { Reduced depreciation allowances }\end{array}$ \\
\hline Taxpayer Relief Act of 1997 & $105-34$ & Permanent & 4.6 years & & $\begin{array}{l}\text { Harmonized asset lives for alternative } \\
\text { minimum tax with regular tax lives }\end{array}$ \\
\hline $\begin{array}{l}\text { Job Creation and Worker } \\
\text { Assistance Act of } 2002\end{array}$ & $107-147$ & $\begin{array}{l}\text { Temporary: } \\
3 \text { years }\end{array}$ & 1.2 years & & Introduced $30 \%$ bonus depreciation \\
\hline
\end{tabular}




\begin{tabular}{|c|c|c|c|c|c|}
\hline Law Name & $\begin{array}{l}\text { Public } \\
\text { Law No. }\end{array}$ & $\begin{array}{l}\text { Stated } \\
\text { Duration }\end{array}$ & $\begin{array}{l}\text { Actual } \\
\text { Duration }\end{array}$ & $\begin{array}{l}\text { Change to Investment } \\
\text { Tax Credit }\end{array}$ & $\begin{array}{l}\text { Change to Depreciation } \\
\text { Allowance }\end{array}$ \\
\hline $\begin{array}{l}\text { Jobs and Growth Tax Relief } \\
\text { Reconciliation Act of } 2003\end{array}$ & $108-27$ & $\begin{array}{l}\text { Temporary: } \\
1.6 \text { years }\end{array}$ & 1.6 years & & $\begin{array}{l}\text { Increased bonus depreciation to } 50 \% \\
\text { for given asset classes }\end{array}$ \\
\hline $\begin{array}{l}\text { The Economic Stimulus Act of } \\
2008\end{array}$ & 110-185 & $\begin{array}{l}\text { Temporary: } \\
1 \text { year }\end{array}$ & 1 year & & Reintroduced $50 \%$ bonus depreciation \\
\hline $\begin{array}{l}\text { American Recovery and } \\
\text { Reinvestment Act of } 2009\end{array}$ & $111-5$ & $\begin{array}{l}\text { Temporary: } \\
1 \text { year }\end{array}$ & 1 year & & Extended 50\% bonus depreciation \\
\hline $\begin{array}{l}\text { Small Business Jobs Act of } \\
2010\end{array}$ & $111-240$ & $\begin{array}{l}\text { Temporary: } \\
1 \text { year }\end{array}$ & 0.2 years & & Extended 50\% bonus depreciation \\
\hline $\begin{array}{l}\text { Tax Relief, Unemployment } \\
\text { Insurance Reauthorization, Job } \\
\text { Creation Act of } 2010\end{array}$ & $111-312$ & $\begin{array}{l}\text { Temporary: } \\
3 \text { years }\end{array}$ & 2.1 years & & $\begin{array}{l}\text { Extended and increased bonus } \\
\text { depreciation to } 100 \%\end{array}$ \\
\hline $\begin{array}{l}\text { The American Taxpayer Relief } \\
\text { Act of } 2012\end{array}$ & $112-240$ & $\begin{array}{l}\text { Temporary: } \\
1 \text { year }\end{array}$ & 1 year & & $\begin{array}{l}\text { Extended and reduced bonus } \\
\text { depreciation to } 50 \%\end{array}$ \\
\hline $\begin{array}{l}\text { The Tax Increase Prevention } \\
\text { Act of } 2014\end{array}$ & 113-295 & $\begin{array}{l}\text { Temporary: } 1 \\
\text { year }\end{array}$ & 1 year & & Extended 50\% bonus depreciation \\
\hline
\end{tabular}

Notes. The legislative history from 1954-2003 comes from Romer and Romer (2009) and Yang (2007). Details on the effects of each law on the ITC and depreciation allowances are based on the author's calculations using information from Gravelle (1994). Narrative legislative information for investment subsidies from 2002-2015 provided by the authors and also using House and Shapiro (2008). Table A.1 provides Romer and Romer (2009) classification of tax changes according to their stated motivation and whether they were influenced by contemporaneous economic events. The table does not include the passage of the Protecting Americans from Tax Hikes (PATH) act in late 2015 which again extended bonus depreciation. As written, the PATH act is temporary in that it calls for bonus depreciation to be phased-out in 2018-2019. 
TABle 3. Effects of InVestment Subsidies: Equipment Production AND PuRChases

\begin{tabular}{|c|c|c|c|c|}
\hline \multirow[b]{2}{*}{ Dependent Variable } & \multicolumn{4}{|c|}{ Specification } \\
\hline & $\begin{array}{l}\text { Constant and linear } \\
\text { trend }\end{array}$ & $\begin{array}{l}\text { Macro covariates } \\
\text { excluding oil }\end{array}$ & Macro covariates & $\begin{array}{l}\text { Leads and lags of } \\
\text { subsidy }\end{array}$ \\
\hline Production & $\begin{array}{c}1.12 \\
(0.36)\end{array}$ & $\begin{array}{c}1.14 \\
(0.32)\end{array}$ & $\begin{array}{c}1.08 \\
(0.40)\end{array}$ & $\begin{array}{c}1.19 \\
(0.41)\end{array}$ \\
\hline Purchases & $\begin{array}{c}1.94 \\
(0.44)\end{array}$ & $\begin{array}{c}1.97 \\
(0.36)\end{array}$ & $\begin{array}{c}1.76 \\
(0.43)\end{array}$ & $\begin{array}{c}1.97 \\
(0.43)\end{array}$ \\
\hline $\begin{array}{l}\text { Difference of coefficients: } \\
\text { Purchases - Production }\end{array}$ & $\begin{array}{c}0.82 \\
(0.15)\end{array}$ & $\begin{array}{c}0.83 \\
(0.13)\end{array}$ & $\begin{array}{c}0.68 \\
(0.13)\end{array}$ & $\begin{array}{c}0.77 \\
(0.15)\end{array}$ \\
\hline
\end{tabular}




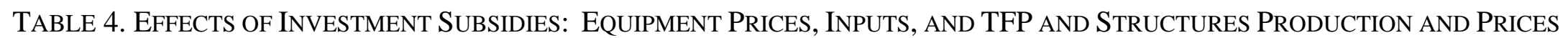

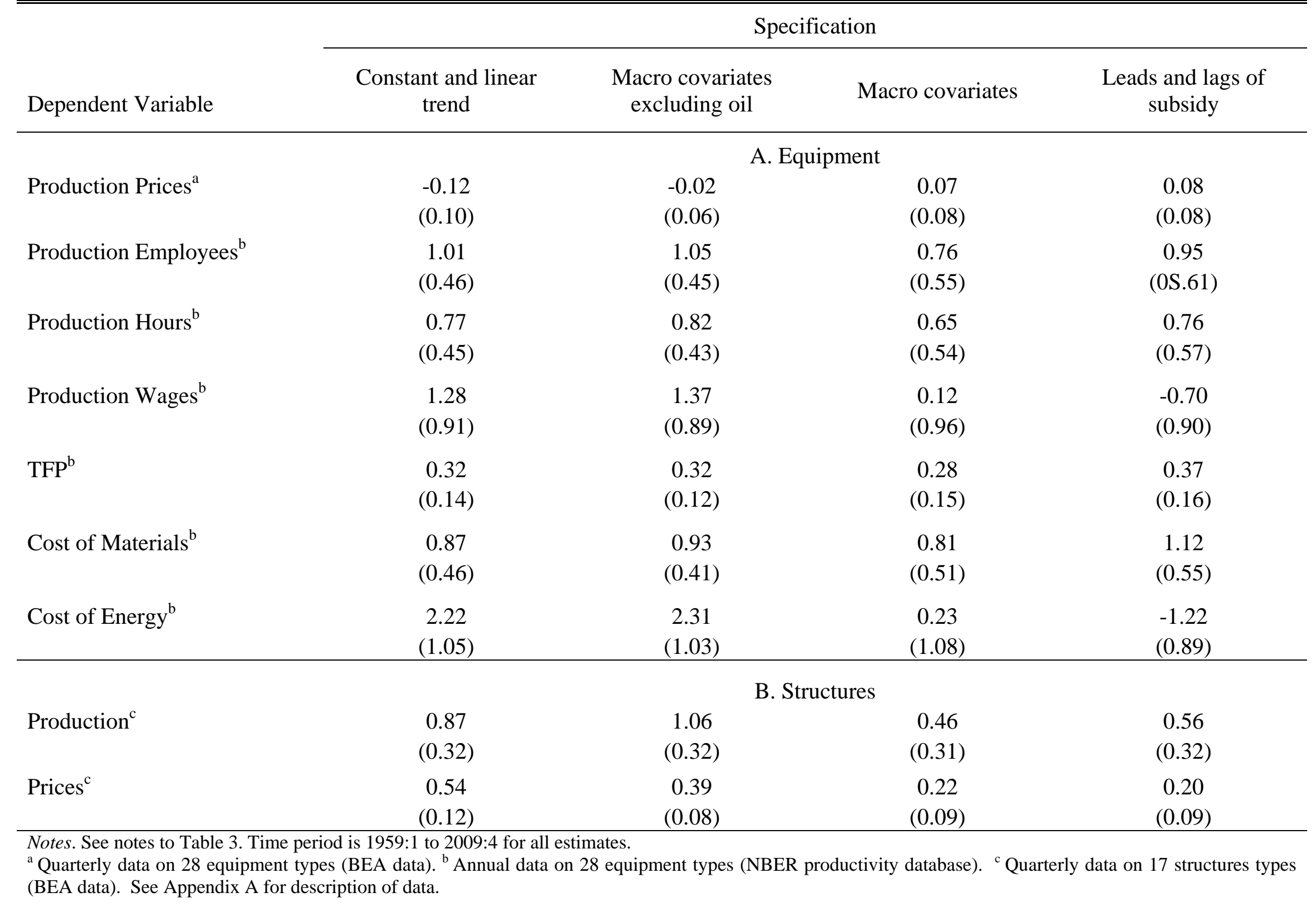


TABle 5.A CALIBRATED PARAMETERS

\begin{tabular}{ccl}
\hline \hline Parameter & $\begin{array}{c}\text { Baseline } \\
\text { calibration }\end{array}$ & \multicolumn{1}{c}{ Notes } \\
\hline$\delta^{m}$ & $\begin{array}{c}0.99 \\
\text { See Tables 1A } \\
\text { and 1B } \\
\gamma_{m}\end{array}$ & See Tables 1A \\
and 1B & Set to imply empirical investment shares. \\
$\sigma$ & 0.2 & Intertemporal elasticity of substitution to annual discount rate of 4 percent \\
$\eta$ & 0.5 & Frisch labor supply elasticity \\
$\rho$ & 0.01 & Elasticity of substitution for materials \\
$\alpha$ & 0.38 & Capital share \\
$\tau^{N}$ & 0.36 & Marginal tax rate on labor income \\
$\tau^{\pi}$ & 0.43 & Marginal tax rate on business profits \\
$g$ & 0.333 & $\begin{array}{l}\text { Steady state ratio of government spending to } \\
\text { consumption }\end{array}$ \\
$\mu_{x}$ & Implied by & Materials share for investment producers \\
$\mu_{h}$ & 0.75 & Capital sub-elasticity for investment producers \\
& & \\
\hline & & \\
\hline
\end{tabular}


TABLE 5.B. BASELINE AND ALTERNATIVE CALIBRATIONS

\begin{tabular}{ccccl}
\hline Parameter & $\begin{array}{c}\text { Baseline } \\
\text { calibration }\end{array}$ & Low value & High value & \multicolumn{1}{c}{ Notes } \\
\hline$\lambda$ & 0.9167 & 0.8750 & 0.9375 & Persistence of tax changes (quarterly autocorrelation) \\
$\xi^{n}$ & 1.00 & 0.00 & 4.00 & Labor adjustment cost \\
$\xi^{h}$ & 8.00 & 2.00 & 16.00 & Capital adjustment cost \\
$\theta$ & 0.50 & 0.01 & 0.99 & Production elasticity of effort \\
$\psi_{n}$ & 1.00 & 0.25 & 1.75 & Sectoral labor supply substitution \\
\hline
\end{tabular}

Notes: The baseline value for the tax persistence parameter corresponds to a 3-year expected duration. The upper and lower values for the persistence parameter imply 4-year and 2-year expected durations. The baseline value for the adjustment cost parameter implies a doubling time for labor of 1 quarter and a doubling time for capital of 2 years. The high adjustment cost calibration implies a doubling time for labor of 1 year and a doubling time for capital of 4 years. 
TABLE 6. INDIRECT INFERENCE ESTIMATES AND MODEL COMPARISON

\begin{tabular}{|c|c|c|c|c|c|c|c|c|c|c|}
\hline Model Specification & Data & Baseline & Low $\lambda$ & High $\lambda$ & Low $\theta$ & High $\theta$ & $\begin{array}{l}\text { Low adj. } \\
\text { costs }\end{array}$ & $\begin{array}{l}\text { High adj. } \\
\text { costs }\end{array}$ & Low $\psi_{n}$ & High $\psi_{n}$ \\
\hline Estimated Import Supply & & 6.53 & 7.22 & 5.17 & 3.06 & 24.14 & 13.99 & 3.13 & 5.02 & 16.31 \\
\hline Elasticity $(\chi)$ & & $(1.56)$ & $(1.61)$ & $(1.36)$ & $(0.84)$ & (11.68) & $(2.43)$ & $(0.95)$ & $(1.12)$ & $(5.41)$ \\
\hline $\begin{array}{l}\text { Targeted Reduced-form } \\
\text { coefficients }\end{array}$ & \multicolumn{10}{|c|}{ Reduced-Form Coefficients Implied by Model } \\
\hline Equipment Production & $\begin{array}{c}1.08 \\
(0.40)\end{array}$ & 1.02 & 1.03 & 1.01 & 1.00 & 1.13 & 1.03 & 0.99 & 1.03 & 0.98 \\
\hline Equipment Investment & $\begin{array}{c}1.76 \\
(0.43)\end{array}$ & 1.59 & 1.73 & 1.45 & 1.42 & 1.88 & 1.73 & 1.43 & 1.54 & 1.74 \\
\hline Hours & $\begin{array}{c}0.65 \\
(0.54)\end{array}$ & 0.58 & 0.59 & 0.58 & 0.64 & 0.57 & 0.56 & 0.61 & 0.45 & 0.81 \\
\hline Material Inputs & $\begin{array}{c}0.81 \\
(0.51)\end{array}$ & 1.02 & 1.03 & 1.01 & 1.00 & 1.13 & 1.03 & 0.99 & 1.03 & 0.98 \\
\hline Productivity (TFP) & $\begin{array}{c}0.28 \\
(0.15)\end{array}$ & 0.04 & 0.04 & 0.04 & 0.00 & 0.08 & 0.04 & 0.04 & 0.05 & 0.02 \\
\hline
\end{tabular}

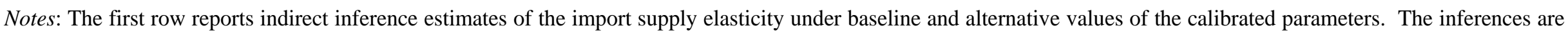

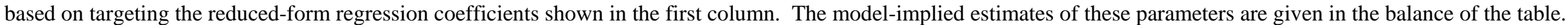

